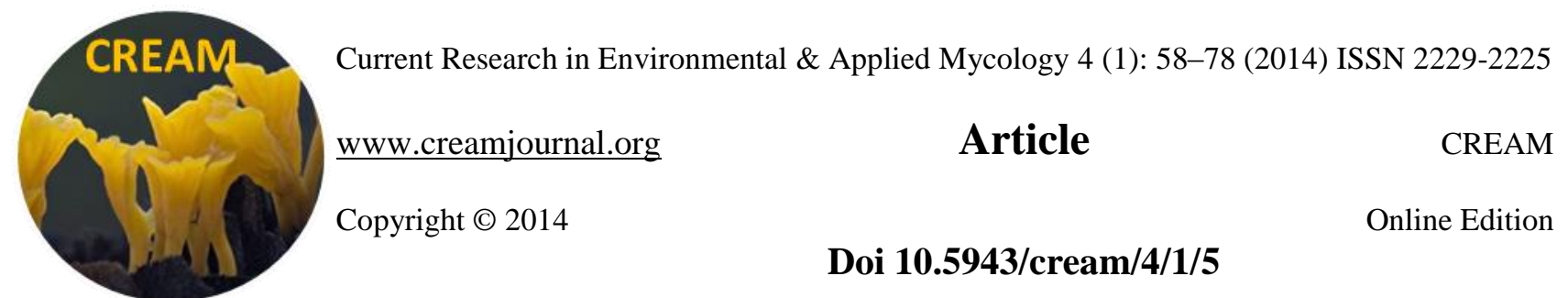

\title{
Diversity of agarics (gilled mushrooms) of Maharashtra, India
}

\section{Senthilarasu G}

9/174, Gandhi Street, Senneerkuppam, Poonamallee, Chennai 600056, Tamil Nadu, India. Email senthilarasug@rediffmail.com, senthilarasug28@gmail.com

Senthilarasu G 2014 - Diversity of agarics (gilled mushrooms) of Maharashtra, India. Current Research in Environmental \& Applied Mycology 4(1), 58-78, Doi 10.5943/cream/4/1/5

\begin{abstract}
A total of 13 species belonging to 10 genera in 9 families collected from Pune and Western Ghats of Mahabaleshwar and Mulshi have been described. Among them, Amanita flavofloccosa is being repoted for the first time from Western Ghats. The remaining species are being reported for the first time from Maharashtra state. Further, 14 species already reported from Maharashtra were also collected from different regions in the present study. In addition, a checklist of gilled mushrooms of Maharashtra is provided on the basis of published reports. A total of 178 species in 68 genera (including 21 new species and two new genera Chlorolepiota and Singerina) belonging to 23 families and 5 orders (Agaricales, Boletales, Cantharellales, Polyporales and Russulales) have been described from Maharashtra. Twenty six new species and 7 new varieties that are contravening particular Articles of the Code are excluded.
\end{abstract}

Key words - Agaricomycetes - checklist - macrofungi - taxonomy - Western Ghats

\section{Introduction}

Maharashtra is the third largest state of India next to Rajasthan and Madhya Pradesh covering an area of $307,713 \mathrm{~km}^{2}$ adjoined by Karnataka to the south, Goa to the southwest, Andhra Pradesh to the southeast and Chhattisgarh to the east. In west, it is borded by Arabian Sea and the northwest by Gujarat and the Union territory of Dadra and Nagar Haveli and north by Madhya Pradesh. It lies at $18^{\circ} 57^{\prime} 36^{\prime \prime} \mathrm{N} 72^{\circ} 49^{\prime} 12^{\prime \prime} \mathrm{E}$, and altitude ranges from $0-1800 \mathrm{~m}$ above mean sea level and the forests cover less than one fifth of the state and confined to the Western Ghats and eastern Vidarbha region. It receives an annual rain fall of about $4000 \mathrm{~mm}$ in the western region of Western Ghats and about 700-1250 $\mathrm{mm}$ in Vidarbha region brought by south west monsoon and the dry zone occurs in between western and Vidarbha region. The forests of Western Ghats and Vidarbha region are rich in mycobiota. The diversity of agarics (gilled mushrooms) occurring in Maharashtra was largely studied by Trivedi (1972) in Vidarbha region and Sathe \& Rahalkar (1975) and Sathe \& Deshpande (1980b) in western region. However, there are no reports on agaric diversity of Maharashtra for the past two decades since studies were started in the period of Massee (1901) and ended two decades back. Recently, Hedawoo \& Mohite (2008) and Hedawoo (2010) studied the diversity of edible, non edible and medicinal mushrooms of Amravati \& Melghat regions. However, taxonomic descriptions of the species were not provided in those studies. The National Fungal Culture Collection of India (NFCCI, WDCM 932) has been established at Agharkar Research Institute (ARI) to conserve the germ plasm of diverse group of fungi occurring in different substrates. Therefore, the study on the diversity of mushrooms 
occurring in Western Ghats has been initiated again at NFCCI (Senthilarasu et al. 2010a, b, c, 2012, Senthilarasu \& Singh 2012, 2013, Senthilarasu 2013a, b). During the period between 2008 and 2012, several collections were made from Agharkar Research Institute campus, Pune University campus, and the Western Ghats of Mahabaleshwar and Mulshi. In this paper, a total of 13 agaric species that are new to Maharashtra state have been described. Fourteen species already reported from Maharashtra were also collected from different regions in the present study and presented in the checklist. In addition, a checklist of agarics occurring in Maharashtra state is provided.

\section{Materials \& Methods}

In general, the morphotaxonomic features of Largent (1977) and Singer (1986) are mainly followed. The microscopic details were studied from thin sections made from dried specimen, revived in $10 \% \mathrm{KOH}$, and stained in $2 \%$ phloxine, cotton blue, cresyl blue and Melzer's reagent. Approximately 50 basidiospores from sections were measured excluding the apiculus and ornamentation. The spore quotient (Q) was obtained by mean length divided by mean width ratio of a spore in profile view. The range of spore measurements with extreme values in parentheses precedes the mean spore measurement in parentheses. The colour terms and notations are from Kornerup \& Wanscher (1978). Exsiccata were deposited at Ajrekar Mycological Herbarium (AMH), Agharkar Research Institute, Pune, India and preserved in personal collections (Macrofungal Collection of India, MCI). The checklist on gilled mushrooms of Maharashtra is prepared on the basis of validly published reports. The Index Fungorum (www.indexfungorum.org) and Species Fungorum (www.speciesfungorum.org) websites are followed for the nomenclature and currently accepted name respectively. The names of the species and author citations as reported in the cited publications are replaced by currently accepted names with author citations. All the new species that are contravening particular Articles in the Code are excluded and presented at the end of the list. The checklist is organized alphabetically by family, genus and species. Several corrections are made where orthographic varients found in the cited publications.
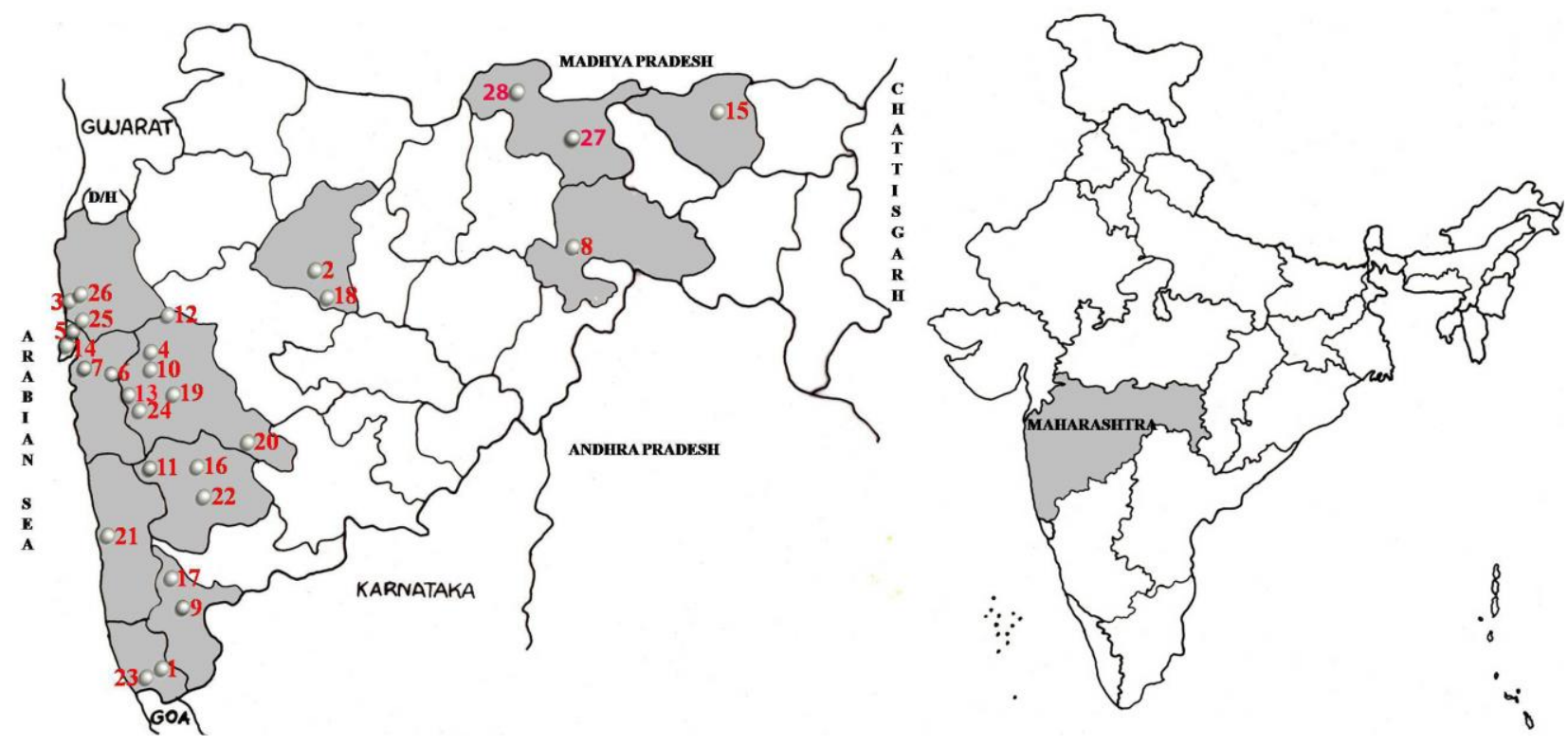

Fig. 1a - Place of collection in Maharashtra state. 1b - Map of Maharashtra in India: 1, Amb = Amboli. 2, Aur $=$ Aurangabad. 3, Bas $=$ Bassein. 4, Bhi $=$ Bhimashankar. 5, Bor $=$ Borivili. 6, Kan $=$ Kanakeshwar. 7, Kar $=$ Karnala. 8, Kha $=$ Khandala. 9, Kol $=$ Kolhapur. 10, Lon $=$ Lonavala. 11, Mah = Mahabaleshwar. 12, Mal = Malshej Ghat. 13, Mul = Mulshi. 14, Mum = Mumbai. 15, Nag = Nagpur. 16, Pai $=$ Panchgani. 17 , Pan $=$ Panhala. 18 , Pha $=$ Phaltan. 19, Pun $=$ Pune .20 , Pur $=$ Purandhar. 21, Rad = Radhanagari. 22, Sat $=$ Satara. 23, Saw $=$ Sawantwadi. 24 , Sin $=$ Sinhgad. 25 , Tha $=$ Thane. 26, Thu $=$ Thungareshwar. 27, Amr $=$ Amravathi. $28, \mathrm{Mel}=$ Melghat. Not to scale. 


\section{Results \& Discussion}

Amanita flavofloccosa Nagas. \& Hongo, Trans. Mycol. Soc. Japan 25(4): 367 (1984) Figs. 2a, b

Pileus 55-100 mm diam., plano-convex to applanate, shallowly, broadly depressed at the disc; surface moist, becoming sticky when wet, uniformly pale orange (5A3) to light orange (6A46A5) covered by numerous, more or less concentrically arranged, brownish orange (7C4) to reddish brown (9E8), appressed to recurved, plate like squamules to granula verrucae, becoming darker with age (9D5-9D6); margin non striate, appendiculate with velar remnants concolorous to scales (9E8). Lamellae free, cream to pale yellow (4A3), changing to reddish brown (8D8) on bruising, crowded, 4-12 mm wide. Stipe elongated, 120-175 × 6-9 mm, cylindrical, gradually widening below 7-15 mm diam., at the base, initially with subbulbous base; surface concolorous (5A3, 6A46A5) to the pileus above, covered by reddish brown (9D8) squamules, changing to Venetian red (8D8) on bruising, white to yellowish white (4A2) to orange white (5A2) below, covered by numerous, concolorous squamules, sticky, solid to stuffed. Annulus persistent, membranous, pendent, grooved above, squamulose below, yellowish white (4A2) to orange white (5A2), attached to the upper quarter of the stipe. Volva friable, forming patches adhering to the base, concolorous to the annulus. Odour strong, unpleasant, nauseating. Pileus context thick, up to $9 \mathrm{~mm}$ wide near the stipe, white. Basidiospores (6.5)7-10(13) $\times(5.5) 6-8(9),(8.67 \pm 1.3 \times 6.9 \pm 0.74) \mu \mathrm{m}, \mathrm{Q}=1.25$, subglobose to broadly ellipsoid, hyaline, weakly amyloid, thin-walled with single large guttule.

Collections examined - India, Maharashtra, Pune, Pune University campus $\left(18^{\circ} 31^{\prime} 18.4^{\prime \prime} \mathrm{N}\right.$ $\left.73^{\circ} 49^{\prime} 53.6^{\prime \prime} \mathrm{E}\right)$, Dalbergia and Gliricidia plantations, on ground, solitary to scattered, 16.08.2012, G. Senthilarasu. (MCI 1354).

The species of Amanita flavofloccosa are easily recognizable in the field by medium to large sized basidiomes having orange pileus covered by numerous, concentrically arranged concolorous squamules, elongated, squamulose stipe, with pendent annulus and friable volva. The presence of amyloid basidiospores and non-striate, appendiculate pileal margin, ovoid to elongated, fusiform inflated cells in the universal veil are the distinguishing features well enough to assign this species in the section Lepidella Bas (Bas 1969) of the subgenus Lepidella (Roze) Vaselý emend. Corner \& Bas (Corner \& Bas 1962) of Amanita Pers.

Amanita aureofloccosa Bas (Pegler 1977) differs from A. flavofloccosa in having golden yellow to orange yellow to buff, umbonate pileus, stipe with subterranean bulbous base, covered by dense furfuraceous layer of squamules and more or less globose spores. Amanita albofloccosa Sathe \& S.D. Deshp. (Sathe \& Deshpande 1980b) described from Pune, differs from $A$. flavofloccosa in having smaller pileus (35-40 vs 55-100 $\mathrm{mm}$ diam.), pale yellow surface covered with cinnamon brown scales, slenderer stipe (4-5 vs 6-9 $\mathrm{mm}$ ), floccose annulus and smaller, globose to subglobose basidiospores $(7.3-9.6 \times 6.4-7.7$ vs $6.5-13 \times 5.5-9 \mu \mathrm{m})$. The morphotaxonomic characters of A. flavofloccosa reported from Chennai, Tamil Nadu (Purushothama \& Natarajan 1987) nearly similar to the present collection excluding the spores that are globose to subglobose rather than subglobose to ellipsoid in shape. However, this species is being reported for the first time from Western Ghats.

Hygrocybe alwisii (Berk. \& Broome) Pegler, Kew Bull., Addit. Ser. 12: 66 (1986)

Fig. $2 c$

Pileus 20-80 mm diam., conic, expanded to convex, finally applanate, retaining an umbo, subumbonate; surface uniformly white to yellowish white (2A2), tinted with brownish orange (6C5-7C5) at the disc, slightly viscid, smooth, with a silky sheen; margin entire, becoming rimose, nearly half way to the disc to eroded. Lamellae free to adnexed, whitish to orange white (5A2), thick, up to $7 \mathrm{~mm}$ broad at the disc, waxy, moderately closed with lamellulae of four lengths, edge concolorous with the sides. Stipe $30-75 \times 5-8 \mathrm{~mm}$, equal, slightly attenuated upwards, cylindric, stuffed, becoming fistulose; surface white, smooth, viscid liquid oozed out on injury. Pileus context up to $3 \mathrm{~mm}$ thick at the disc, white. Basidiospores dimorphous: macrospores (6.5)7-9(9.5) $\times(4.5) 5.5-7.5(8.5),(7.7 \pm 0.8 \times 6.4 \pm 0.8) \mu \mathrm{m}, \mathrm{Q}=1.12$, subglobose to broadly ellipsoid, hyaline, 
thin walled with a single large refractive guttule; microspores (3.4)4-5.5(6) $\times(2.9) 3.5-4(4.5)$, $(4.8 \pm 0.5 \times 3.6 \pm 0.3) \mu \mathrm{m}, \mathrm{Q}=1.3$, ellipsoid to broadly ellipsoid, similar to macrospores.

Collections examined - India, Maharashtra, Pune, Pune University campus $\left(18^{\circ} 31^{\prime} 18.4^{\prime \prime} \mathrm{N}\right.$ $73^{\circ} 49^{\prime} 53.6^{\prime \prime E}$ ), Dalbergia and Gliricidia plantations, on ground, solitary to scattered, 01.08.2012, G. Senthilarasu. (MCI 1250), Mulshi $\left(1^{\circ} 26^{\prime} 01.2^{\prime \prime} \mathrm{N} 73^{\circ} 25^{\prime} 47.5^{\prime \prime} \mathrm{E}\right)$, on ground, solitary to scattered, evergreen forest, 30.07.2010, (MCI 1248).

The distinguished features of $H$. alwisii are medium to large, white basidiomes, having conic to applanate, rimose to eroded pileus, adnexed to free lamellae, dimorphous spores and pseudocystidia. The present collection resembles in all morphotaxonomic characters with $H$. alwisii reported by Leelavathy et al. (2006) in Kerala. However, the present collection slightly differs from Kerala collection in having shorter stipe (30-75 vs 65-120 $\mathrm{mm}$ ) and narrower macrospores (6.5$9.5 \times 4.5-8.5$ vs $7-10.5 \times 6-10 \mu \mathrm{m})$.

Hygrocybe astatogala (R. Heim) Heinem., Bull. Jard. bot. État Brux. 33(2): 436 (1963) ～Fig. 2e

Pileus 10-35 mm diam., conical, up to $32 \mathrm{~mm}$ high, subumbonate; surface uniformly deep red (10C8) to brownish red (10D8) to reddish brown (9D8), yellowish white (3A2-4A2) at extreme margin, covered by appressed, blackish fibrils, pellucid striate; margin entire, becoming eroded, blackening. Lamellae free to adnexed, whitish, becoming pale yellow (3A3) to pastel yellow (3A4), becoming black, crowded with 7 different lengths of lamellulae, up to $4 \mathrm{~mm}$ wide, finely eroded. Stipe 80-150 × 6-9 mm, cylindrical, slightly attenuated towards apex, compressed, fistulose; surface whitish below, pale yellow (1A3) to pastel yellow (1A4) to yellowish orange (4A7) above, covered by shiny, blackish fibrils. Pileus context up to $3 \mathrm{~mm}$ thick near stipe, yellowish, becoming black. Basidiospores (7)7.5-9(10) $\times(6) 6.5-7(7.5),(8.43 \pm 0.8 \times 6.7 \pm 0.3) \mu \mathrm{m}$, $\mathrm{Q}=1.24$, ellipsoid to broadly ellipsoid, hyaline, thin walled with numerous guttules.

Collections examined - India, Maharashtra, Mahabaleshwar, Lingamala forest $\left(17^{\circ} 55^{\prime} 17.2^{\prime \prime} \mathrm{N} 73^{\circ} 39^{\prime} 18.3^{\prime \prime} \mathrm{E}\right)$ on ground, solitary to scattered, 16.07.2010, G. Senthilarasu. (MCI 1231).

The conic, deep red to reddish brown pileus covered by blackish fibrils, pale yellow to yellowish orange, elongated stipe, turning whole basidiomes to black on bruising are the distinguished characters. Leelavathy et al. (2006) and Mohanan (2011) reported this species from Western Ghats of Kerala. The Kerala collection of $H$. astatogala reported by Leelavathy et al. (2006) slightly differs in having larger basidiomes $(10-90 \mathrm{~mm}$ diam. pileus) than the present collection.

Laccaria fraterna (Sacc.) Pegler, Aust. J. Bot., Suppl. Ser. 13(2): 332 (1965)

Fig. $2 d$

Pileus 10-30 mm diam., plano-convex, shallowly depressed, dry, hygrophanous; surface raspberry red (10D7) to cardinal red (10D8), paler on drying, smooth; margin undulating, striate. Lamellae subdecurrent to decurrent, concolorous to the pileus, moderately distant with lamellulae of five different lengths. Stipe $10-50 \times 2-6 \mathrm{~mm}$, slightly tapering towards base, slightly compressed at the apex, stuffed becoming hollow; surface white below, reddish brown (10D6) to raspberry red (10D7) above, smooth, arising from white basal mycelial tomentum. Pileus context thin, cream. Basidiospores (6.5)9-10.5(12) $\times(5.5) 8-9(10),(9.6 \pm 0.78 \times 8.3 \pm 0.63) \mu \mathrm{m}, \mathrm{Q}=1.14$, subglobose to short ellipsoid, apiculus prominent, up to $3.5 \times 2 \mu \mathrm{m}$, echinulate, spines up to $2 \mu \mathrm{m}$ long, hyaline, thin walled. Basidia bisporic, bearing two large sterigmata.

Collections examined - India, Maharashtra, Panchgani $\left(17^{\circ} 00^{\prime} 00^{\prime \prime} \mathrm{N} 73^{\circ} 49^{\prime} 12^{\prime \prime} \mathrm{E}\right)$, on ground, solitary to scattered, mycorrhizal, associated with eucalypts, 05.11.2008, G. Senthilarasu. (AMH 9245, 9269), Mulshi, 16.07.2010, (MCI 1235).

Laccaria fraterna is a mycorrhizal species and widely distributed in Panchgani and Mulshi forest areas wherever eucalypts plantations are present. Laccaria laccata (Scop.) Cooke differs from $L$. fraterna in greyish orange to pinkish white to pinkish brown basidiomes and having tetrasporic basidia. 


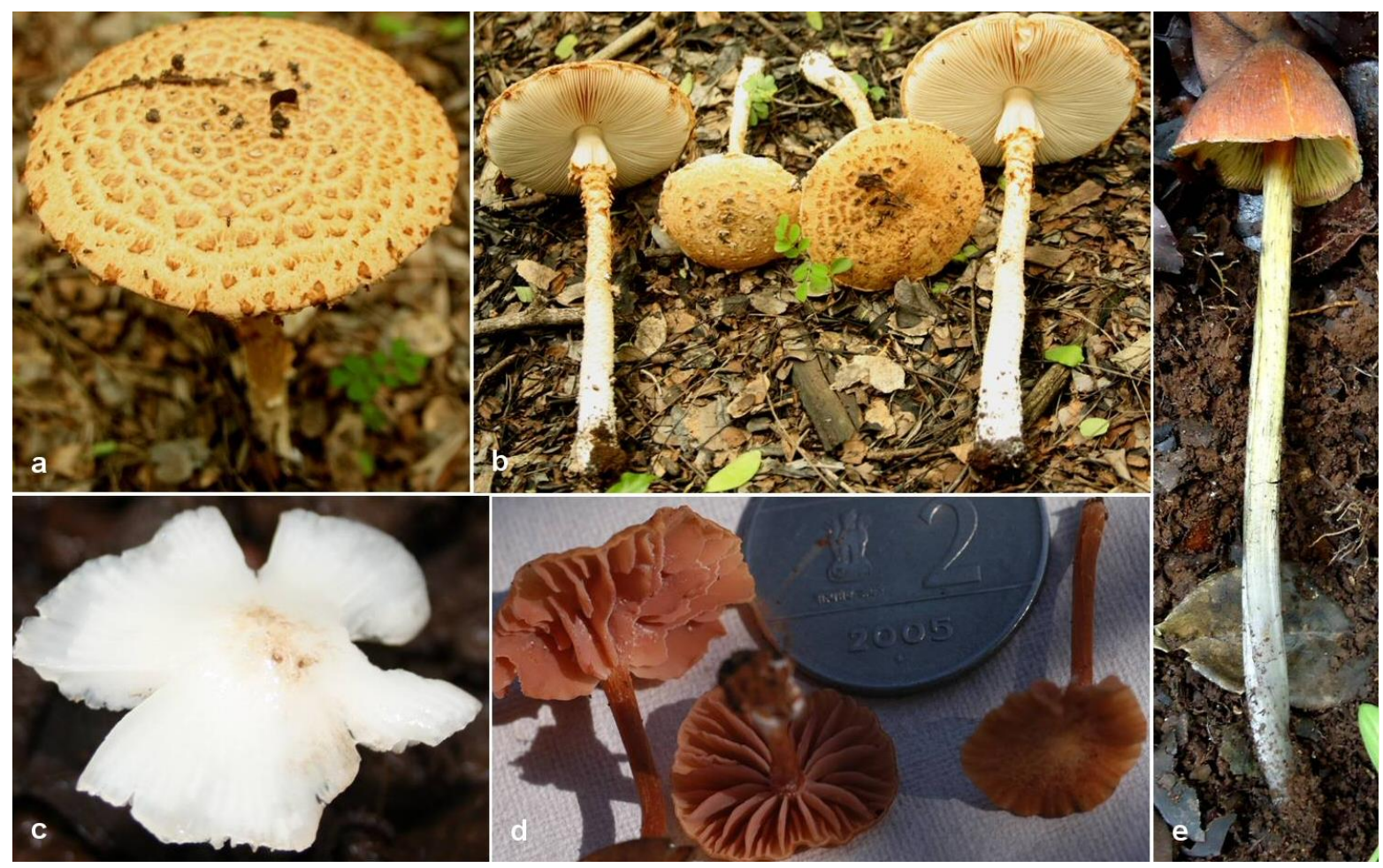

Fig. 2 - a, b Amanita flavofloccosa, basidiomes under natural conditions in Pune University campus. a, surface view. b, Gill view. c, Hygrocybe alwisii basidiome under natural conditions in Mulshi. d, Laccaria fraterna. e, Hygrocybe astatogala basidiome under natural conditions in Mahabaleshwar.

Lactocollybia epia (Berk. \& Broome) Pegler, Kew Bull., Addit. Ser. 12: 77 (1986)

Figs. 3a, b

Pileus 10-30 mm diam., convex, becoming plano-convex, subumbonate; surface dull white to yellowish white (2A2-3A2-4A2), to dull yellow (3B3) to ivory (4B3), smooth, glabrous; margin translucent striate, crisped, becoming eroded. Lamellae adnate, white to yellowish white (2A2$3 \mathrm{~A} 2$ ), up to $2 \mathrm{~mm}$ wide, moderately crowded with numerous lamellulae of five different lengths. Stipe 7-35 × 1-2 mm, thin, central to excentric, tubular, equal, slightly tapering towards apex, subbulbous at the base; surface concolorous with the pileus, smooth, shiny, arising from a white to brown basal tomentum. Pileus context thin, up to $1 \mathrm{~mm}$ wide near the stipe, white. Basidiospores (5.5)6.5-8(8.5) × (3)3.5-4.6, (7.3 $\pm 0.7 \times 4.0 \pm 0.3) \mu \mathrm{m}, \mathrm{Q}=1.8$, elongate, amygdaliform, hyaline, thin-walled, smooth, inamyloid, containing few refractive guttules.

Collections examined - India, Maharashtra, Pune, Pune University campus $\left(18^{\circ} 31^{\prime} 18.4^{\prime \prime} \mathrm{N}\right.$ $73^{\circ} 49^{\prime} 53.6^{\prime \prime} \mathrm{E}$ ), on base of the tree trunk, solitary to scattered to gregarious, 20.07. 2011, G. Senthilarasu. (MCI 1287), 26.07.2012 (MCI 1301), ARI campus $\left(18^{\circ} 52^{\prime} \mathrm{N} 73^{\circ} 83^{\prime} \mathrm{E}\right)$, tree trunk, 22.06.2009, (MCI 1088), Mulshi (18 $26^{\prime} 01.2^{\prime \prime} \mathrm{N} 73^{\circ} 25^{\prime} 47.5^{\prime \prime} \mathrm{E}$ ), on wood, twigs, 06.08.2009 (MCI 1091).

Lactocollybia epia is a common species and widely distributed in Pune University Campus and Mulshi forest areas. This species is easily recognized in the field by dull white to yellowish white, small basidiomes having adnate lamellae, central to excentric, shorter and slender stipe arising from basal tomentum.

Lentinus sajor-caju (Fr.) Fr., Epicr. syst. mycol. (Upsaliae): 393 (1838) [1836-1838]

Fig. 3c

Pileus 45-105 mm diam., soft coriaceous, drying hard and rigid, cyathiform to deeply infundibuliform; surface variable in colour, at first whitish, becoming yellowish white (4A2) to pale yellow (4A3) to greyish yellow (4B3) or pale orange (5A3) to light orange (5A4) to brownish orange (6C5), dry, glabrous, smooth with appressed reddish brown (8D8) squamules especially 

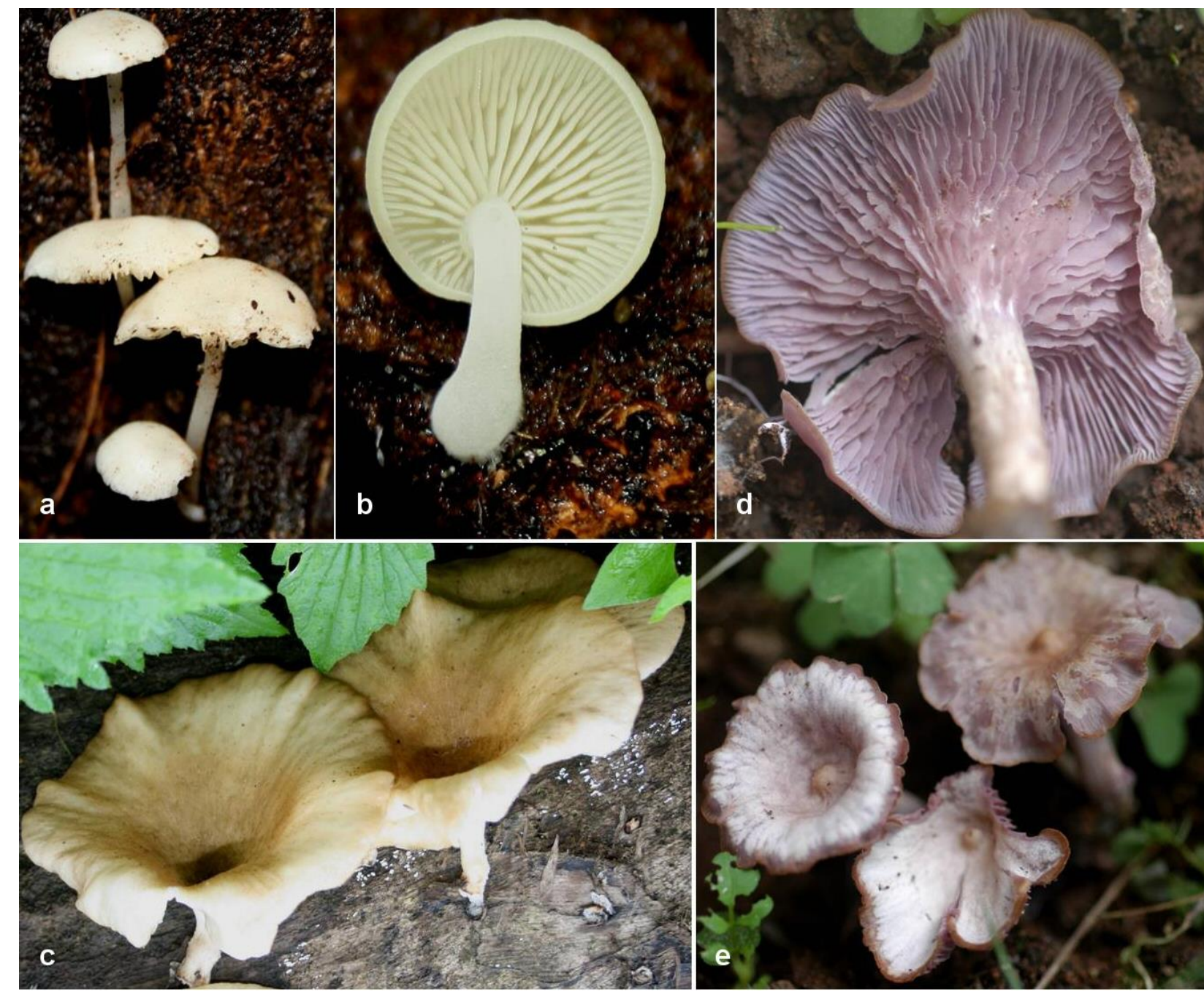

Fig. 3 - a, b Lactocollybia epia, basidiomes under natural conditions in Pune University campus. a, surface view. b, gill view. c, Lentinus sajor-caju basidiomes under natural conditions in Mulshi. d, e Lepista sordida, basdiomes under natural conditions in ARI campus. d, gill view. e, surface view.

towards the centre, finely radially striate to translucent striate, entire, becoming rimose to eroded; margin incurved to straight, thin, undulating to lobed. Lamellae decurrent to deeply decurrent, whitish, up to $1 \mathrm{~mm}$ thick, wavy, crowded with numerous lamellulae. Stipe central to slightly excentric, short, 10-20 × 5-6 mm, cylindric, solid; surface white, becoming blackish at the base. Annulus fugaceous. Pileus context thin, whitish. Basidiospores (5)6.5-7(8.5) $\times 2-2.5(3),(6.7 \pm 0.3$ $\times 2.5 \pm 0.3) \mu \mathrm{m}, \mathrm{Q}=2.0$, cylindric, hyaline, thin-walled with few refractive guttules.

Collections examined - India, Maharashtra, Mulshi, $\left(18^{\circ} 26^{\prime} 01.2^{\prime \prime} \mathrm{N} 73^{\circ} 25^{\prime} 47.5^{\prime \prime} \mathrm{E}\right)$, solitary to gregarius, on wood, 15.09.2011. Coll. G. Senthilarasu. (AMH 9569).

Lentinus sajor-caju can easily be recognized in the field by its large, thin, whitish to cream pileus with pale brown disc, lacking or with small squamules at the center, short stipe with annulus or annular ridge. The characters of present collection agree with the description provided by Pegler (1983).

Lepista sordida (Schumach.) Singer, Lilloa 22: 193 (1951) [1949]

Figs. 3d, e

Pileus 20-55 mm diam., broadly convex, deeply infundibuliform, acutely umblicate; surface greyish lilac (15C2-15C3) to dull violaceous (16B2-16B3) with reddish brown umbo (9D4), strongly hygrophanous to greyish orange (6B3), greyish red (8C3), glabrous, smooth; margin incurved becoming applanate, finally uplifted and lobate, pellucid-striate to striate. Lamellae sinuate-adnate to subdecurrent, greyish lilac (15C2-16B2) to dull lillac (15C3), 
becoming greyish Magenta (13D3-14D3), 2-5 mm broad, crowded with lamellulae of 6 different lengths, often eroded. Stipe $20-50 \times 2-6 \mathrm{~mm}$, cylindric, equal, often sinuous, solid becoming fistulose; surface concolorous with the pileus, smooth, longitudinally fibrillose with basal tomentum. Pileus context thin, up to $1 \mathrm{~mm}$ thick, pale violet (15A3). Basidiospores (5)5.5-6(6.5) $\times(3) 3.5-4.5,(5.83 \pm 0.2 \times 4.0 \pm 0.4) \mu \mathrm{m}, \mathrm{Q}=1.45$, ellipsoid, hyaline, thin-walled, finely rugulose, guttulate.

Collections examined - India, Maharashtra, Pune, ARI campus $\left(18^{\circ} 52^{\prime} \mathrm{N} 73^{\circ} 83^{\prime} \mathrm{E}\right)$, on ground, solitary to caespitose, 11.10.2011, G. Senthilarasu. (MCI 1269).

The small to medium sized basidiomes of Lepista sordida are easily recognizable in the field by their grayish lilac to dull lilac, umblicate, hygrophanous pileus, concolorous lamellae and stipe that is often sinuous. Lepista sordida closely resembles L. nuda (Bull.) Cooke (Pegler 1977) in having similar coloured basidiomes. However L. nuda differs clearly in having non hygrophanous, non striate, large pileus, non sinuous, large, thick stipe and slightly larger basidiospores (6-9 vs 5-6.5 $\mu \mathrm{m}$ ). The distinguished features of $L$. nudoidea Sathe \& S.D. Deshp. (Sathe \& Deshpande 1980b) described from Panchgani, Maharashtra are lilac basidiomes having non hygrophanous, non striate pileus and verrucose basidiospores. The morphotaxonomic characters of L. nudoidea are almost similar to $L$. nuda excluding the basidiomes size and slightly smaller spores $(4.8-7.3$ vs $6-9 \mu \mathrm{m})$.

Leucocoprinus fragilissimus (Berk. \& M.A. Curtis) Pat., Essai Tax. Hyménomyc. (Lons-leSaunier): 171 (1900)

Fig. $4 \mathrm{a}$

Pileus 10-15 mm diam., plane; surface light yellow (4A4) to butter yellow (4A5) at the disc, covered by minute, brownish yellow (5C8) squamules, white elsewhere, thin; margin translucent striate to sulcate striate, forming conspicuous ridges and furrows up to the disc, undulating to eroded. Lamellae free, white, thin, $\leq 1 \mathrm{~mm}$ wide, moderately spaced with lamellulae of two different lengths. Stipe 15-30 × 1-2 mm, thin, cylindric with a bulbous base, slightly attenuated towards apex; surface light yellow (4A4) to butter yellow (4A5), smooth, hollow. Annulus membranous, attached to the upper third of the stipe, concolorous to the stipe, fugacious. Pileus context thin, concolorous with the pileus. Basidiospores (9.5)11-13(14) $\times(7) 7.5-8(8.5)$, $(12.3 \pm 0.4 \times 7.8 \pm 0.2) \mu \mathrm{m}, \mathrm{Q}=1.57$, ellipsoid to elongate ellipsoid, truncated at the apex by a small but distinct germ pore, hyaline, dextrinoid, strongly metachromatic in cresyl blue, with a complex wall.

Collections examined: India, Maharashtra, Pune, ARI campus $\left(18^{\circ} 52^{\prime} \mathrm{N} 73^{\circ} 83^{\prime} \mathrm{E}\right)$, on ground, solitary to scattered, 04.08.2012, G. Senthilarasu. (MCI 1311).

Leucocoprinus fragilissimus is recognizable in the filed by slender and delicate basidiomes having translucent, strongly sulcate striate, yellowish, applanate pileus, free, thin, moderately spaced lamellae and slender yellow stipe having evanescent annulus. Leucocoprinus birnbaumii (Corda) Singer differs from L. fragilissimus in having hemispherical to parabolic, yellow pileus covered by concolorous, floccose squamules, sulcate striate half way to the disc and elongated and thicker stipe $(50-95 \times 2-9 \mathrm{~mm})$.

Leucocoprinus birnbaumii (Corda) Singer, Sydowia 15(1-6): 67 (1962) [1961]

Fig. $4 \mathrm{~b}$

Pileus 15-35 mm diam., hemispherical to parabolic; surface pale yellow (2A3) to pastel yellow (1A4) to prime butter yellow (4A5) at the disc, prime rose yellow (1A6) elsewhere, bearing loose scattered, concolorous, minute, floccose squamules; margin sulcate striate, half-way to the disc. Lamellae free, pale yellow (2A3) to sulphur yellow (1A5), thin, up to $5 \mathrm{~mm}$ thick at the disc, ventricose, crowded, with lamellulae of three different lengths; edge smooth, sun yellow (2A5). Stipe $50-95 \times 2-9 \mathrm{~mm}$, cylindric, clavate, with a prominent swollen base, up to $11 \mathrm{~mm}$ diam., hollow, surface concolorous with the pileus, floccose above the annulus, smooth below. Annulus membranous, somewhat evanescent, concolorous with the stipe, attached to upper third of the stipe. Pileus context thin, soft, concolorous with the pileus. Basidiospores $(7.5) 8-10.5(11) \times(5) 5.5-$ 
$6.5(7),(9.3 \pm 0.8 \times 6.0 \pm 0.4) \mu \mathrm{m}, \mathrm{Q}=1.5$, ellipsoid, truncated at the apex by a small but distinct germ pore, hyaline, dextrinoid, strongly metachromatic in cresyl blue, with a complex wall.

Collections examined - India, Maharashtra, Pune, Pune University campus (18 $31^{\prime} 18.4^{\prime \prime} \mathrm{N}$ 7349'53.6"E), on humus, solitary to connate, 21.07.2009, G. Senthilarasu. (MCI 1032).

The characteristic features of Leucocoprinus birnbaumii are the hemispherical to parabolic, yellowish, sulcate striate pileus, covered by concolorous floccose squamules, free lamellae and elongated, concolorous stipe with bulbous base. Leucocoprinus cepistipes (Sowerby) Pat. differs from L. birnbaumii in having white pileus with pale brown disc, white to cream lamellae and concolorous stipe.

Parasola plicatilis (Curtis) Redhead, Vilgalys \& Hopple, in Redhead, Vilgalys, Moncalvo, Johnson \& Hopple, Taxon 50(1): 235 (2001)

Fig. 4c

Pileus 10-40 mm diam., plane, orbicular, membranous; surface brownish orange (6C4-7C5) to light brown (6D8) to burnt Sienna (7D8) at the disc, greyish (6B1), orange grey (6B2) to brownish grey (6C2) to greyish brown (6D3) towards margin; margin radially plicate striate up to the disc. Lamellae adnexed to adnate, greyish (6B1), becoming black, thin, moderately crowded, non deliquescent. Stipe 20-75 $\times 1-2 \mathrm{~mm}$, thin, tubular; surface white, glabrous. Pileus context thin. Basidiospores (9)11-12.5(13) $\times(7) 7.5-9(10),(12.15 \pm 0.6 \times 7.56 \pm 0.3) \mu \mathrm{m}, \mathrm{Q}=1.6$, lenticular to subrhomboid in face view, ellipsoid to elongate ellipsoid in side view, thick walled with truncate germ pore, black.

Collections examined - India, Maharashtra, Pune, ARI campus $\left(18^{\circ} 52^{\prime} \mathrm{N} 73^{\circ} 83^{\prime} \mathrm{E}\right)$, on fallen twigs, solitary to gregarious, 20.10.2010, G. Senthilarasu. (MCI 1011).

The distinguished features are orange grey to brownish grey to greyish brown, thin pileus with brownish disc having radially plicate striate margin, non deliquescent lamellae and slender, white, tubular stipe.

Pleurotus djamor (Rumph. ex Fr.) Boedijn, Rumphius Memorial Volume: 292 (1959) Figs. 4d, e Pileus $10-80 \times 10-55 \mathrm{~mm}$ diam., spathulate to flabelliform to dimidate, shallowly to deeply, broadly depressed towards the base; surface colour variable, rust brown (6E8) to henna brown (7E8) near attachment, light brown (6D6) elsewhere or uniformly dull white to yellowish white (2A2-3A2) to pale yellow (3A3-4A3) to orange white (5A2) to pinkish white (7A2-8A2), smooth, glabrous; margin initially involute, entire to incised, faintly striate. Lamellae decurrent, extends up to the base of the stipe or near attachment to the substrate; surface initially white to yellowish white (3A2-4A2) to pale yellow (3A3), becoming pinkish white (7A2-8A2) to pale red (7A3-8A3) to pastel red (9A4) near margin, crowded with lamellulae of five different lengths, often forked near attachment, up to $5 \mathrm{~mm}$ broad; margin entire. Stipe absent or reduced, 5-20 × 3-10 $\mathrm{mm}$, lateral, cylindric, equal to slightly tapering towards base; surface white, smooth, solid arising from white to yellowish white (4A2) mycelium. Pileus context thin, up to $5 \mathrm{~mm}$ thick, white. Basidiospores (5.5) 6-7.5(8) $\times(3) 3.5-4(4.5),(7.3 \pm 0.2 \times 3.4 \pm 0.3) \mu \mathrm{m}, \mathrm{Q}=2.14$, cylindric, smooth, hyaline, thin walled.

Collections examined - India, Maharashtra, Pune $\left(18^{\circ} 31^{\prime} 13^{\prime \prime} \mathrm{N} 73^{\circ} 51^{\prime} 24^{\prime \prime} \mathrm{E}\right)$, on rotten wood, imbricate, 21.09.2012, G. Senthilarasu. (MCI 1300).

The distinguished characters are imbricate, astipitate to reduced stipitate basidiomes having brown to yellowish white to pinkish white pileus, decurrent, yellowish white to pinkish white lamellae.

Pleurotus cystidiosus O.K. Mill., Mycologia 61: 881-893 (1969)

Fig. $4 \mathrm{f}$

Pileus $30-80 \times 20-70 \mathrm{~mm}$ diam., flabelliform to dimidate to convex, shallowly to broadly depressed near attachment; surface uniformly yellowish white (4A2) to pale yellow (4A3) to grayish yellow (4B4), smooth, glabrous; margin entire, not striate, incurved. Lamellae decurrent, white to yellowish white (4A2), crowded with numerous lamellulae of six different lengths, up to 7 $\mathrm{mm}$ broad, sometimes forked near margin, intervenose near attachment with the stipe. Stipe short, 
15-30 × 7-20 mm, excentric to lateral, fleshy, terete, equal; surface concolorous to the pileus, smooth, sometimes faintly reticulate near attachment with the lamellae, solid. Pileus context thick, up to $25 \mathrm{~mm}$ wide near stipe, white. Basidiospores (11)11.5-13.5(14) $\times(4) 4.5-5(6),(12.3 \pm 0.4 \times$ $4.9 \pm 0.3) \mu \mathrm{m}, \mathrm{Q}=2.51$, cylindric, smooth, hyaline, thin walled.

Collections examined - India, Maharashtra, Pune, ARI campus $\left(18^{\circ} 52^{\prime} \mathrm{N} 73^{\circ} 83^{\prime} \mathrm{E}\right)$, on tree trunk, caespitose, 02.09.2009, G. Senthilarasu. (MCI 989).

The characteristic features are medium to large, fleshy fruit bodies having white to yellowish white pileus, excentric to lateral stipe and presence of pleuro- and cheilocystidia. The formation of anamorph, Antromycopsis Pat. \& Trab. in culture is the distinguished character to assign this species in the subgenus Coremiopleurotus. The macro- and microcharacters of this species are similar to Pleurotus cystidiosus reported by Natarajan \& Raman (1983). However, the present species slightly differs in having non striate pileus and excentric to lateral stipe.

Trogia infundibuliformis Berk. \& Broome, J. Linn. Soc. Bot. 14(73): 45 (1873) [1875] Fig. 4g

Pileus 7-35 mm diam., plane, becoming deeply infundibuliform, perforated, splitting radially almost to the disc, membranous; surface light brown (7D4-8D4), darker towards center, brownish orange (7C3) at the margin, smooth, glabrous, translucent striate to rimose, splitting up to the disc; margin undulate, incurved to decurved. Lamellae subdecurrent to deeply decurrent, brownish orange (7C3) to dull red (8C3) to grayish brown (8D3), distant with lamellulae of 3 different lengths, $\leq 1 \mathrm{~mm}$ wide. Stipe 5-12 $\times 1-4 \mathrm{~mm}$, very short, arising from white discoid base, excentric to central, tubular, tough; surface concolorous with the pileus, slightly pinkish at the apex, pruinate above, smooth below. Pileus context very thin, concolorous with the pileus. Basidiospores 6-7(7.5) $\times(3) 3.5-4.5(5),(6.6 \pm 0.3 \times 3.7 \pm 0.2) \mu \mathrm{m}, \mathrm{Q}=1.78$, ellipsoid to elongate ellipsoid, hyaline, thin walled, inamyloid.

Collections examined - India, Maharashtra, Mahabaleshwar (1755'17.2"N 73³9'18.3"E), solitary to scattered, on twigs, 30.08.2012, G Senthilarasu. (AMH 9568).

Trogia infundibuliformis is distinguished by its small to medium sized basidioms having infundibuliform, perforated, membranous, splited pileus, decurrent, distant lamellae and central to excentric stipe arising from white, discoid base. Trogia cantharelloides (Mont.) Pat. (Pegler 1983) differs from $T$. infundibuliformis in having crowded lamellae and smaller spores $(3.7-5.5 \times 2.3-3$ vs $5.5-7.5 \times 3-5 \mu \mathrm{m})$.

A total of 13 species belonging to 10 genera in 9 families (Agaricaceae-Leucocoprinus birnbaumii, L. fragilissimus; Amanitaceae-Amanita flavofloccosa; Hydnangiaceae-Laccaria fraterna; Hygrophoraceae-Hygrocybe alwisii, H. astatogala; Marasmiaceae-Lactocollybia epia, Trogia infundibuliformis; Pleurotaceae-Pleurotus cystidiosus, P. djmor; Polyporaceae-Lentinus sajor-caju; Psathyrellaceae-Parasola plicatilis; Tricholomataceae-Lepista sordida) have been described and discussed. An ectomycorrhizal fungus Lacccaria fraterna is widely distributed in Panchagani and Mulshi forest areas wherever eucalyptus plantations are present. A lignicolous and litter fungus Lactocollybia epia is widely distributed in Pune University Campus and Mulshi forests and fruits every year during July to August. Although, Hygrocybe alwisii grows solitarily, this species is also distributed in Pune University campus and Mulshi forest areas. Besides, 14 species already reported from Maharashtra were also collected from different regions in the present study and listed in the Table 1. Among them, Macrolepiota procera was collected from Mahabaleshwar, Mulshi and Bhimashankar. Schizophyllum commune and Anthracophyllum nigritum were widely distributed in Mahabaleshwar and Mulshi. Hymenopellis radicata was collected from Bhimashankar and Lonavala.

In the checklist, a total of 178 species in 68 genera belonging to 23 families and five orders (Agaricales, Boletales, Cantharellales, Polyporales and Russulales) have been reported from Maharashtra. The species of Panaeolus and Volvariella are placed in incerte sedis and the later genus has been placed outside the pluteoid clade in a study by Justo et al. (2010, 2011). However, for most of the species, only name has been listed without descriptions in the publications. 
Table 1 Checklist of species of gilled fungi occurring in Western Ghats of Maharashtra

\begin{tabular}{|c|c|c|}
\hline Taxa & Distribution & References \\
\hline \multicolumn{3}{|l|}{ Agaricaceae Chevall. } \\
\hline Agaricus abruptibulbus Peck & Pun & Sathe \& Rahalkar 1976, Sathe \& Deshpande 1982 \\
\hline \multirow[t]{3}{*}{ Agaricus arvensis Schaeff } & Nag & Trivedi 1972 \\
\hline & Pun & Sathe \& Rahalkar 1976, Sathe \& Deshpande 1982 \\
\hline & Sat & Chavan \& Barge 1977 \\
\hline Agaricus bisporus (J.E. Lange) & Pun & Sathe \& Rahalkar 1976; Sathe \& Deshpande 1982 as $A$. \\
\hline Imbach & & bisporus var. albidus (J.E. Lange) Singer \\
\hline Agaricus bitorquis (Quél.) Sacc. & Pun & $\begin{array}{l}\text { Sathe \& Rahalkar 1976, Sathe \& Deshpande } 1982 \text { as } \\
\text { Agaricus rodmanii Peck }\end{array}$ \\
\hline Agaricus brunnescens Peck & Pun & Sathe \& Deshpande $1980 \mathrm{~b}$ \\
\hline \multirow[t]{5}{*}{ Agaricus campestris L." } & Pun & $\begin{array}{l}\text { Sathe \& Rahalkar 1975, Sathe \& Deshpande 1982; } \\
\text { Parandekar } 1964 \text { as Psalliota campestris L. Quél., }\end{array}$ \\
\hline & Pun & MCI 967 \\
\hline & $\mathrm{Nag}$ & Trivedi 1972 \\
\hline & Mah & Sathe \& Deshpande 1980b \\
\hline & Amr & Hedawoo 2010 \\
\hline Agaricus micromegethus Peck & Pun & $\begin{array}{l}\text { Sathe \& Rahalkar 1976, Sathe \& Deshpande } 1982 \text { as } \\
\text { Agaricus micromegatha }\end{array}$ \\
\hline Agaricus pattersoniae Peck & Pun & Sathe \& Rahalkar 1976, Sathe \& Deshpande 1982 \\
\hline \multirow[t]{2}{*}{ Agaricus placomyces Peck } & Pun & Sathe \& Rahalkar 1976, Sathe \& Deshpande 1982 \\
\hline & Amr & Hedawoo 2010 \\
\hline Agaricus scitulus Massee & Aur & $\begin{array}{l}\text { Sathe \& Sasangan 1977, Sathe \& Deshpande } 1982 \text { as } \\
\text { Anellaria scitula (Massee) Sacc. }\end{array}$ \\
\hline Agaricus semotus Fr. & Pun & Sathe \& Deshpande 1982 \\
\hline Agaricus subedulis Heinem. & Pha & Sathe \& Deshpande $1980 \mathrm{~b}$ \\
\hline Agaricus sylvaticus Schaeff. & Pun & Sathe \& Rahalkar 1976, Sathe \& Deshpande 1982 \\
\hline Agaricus sylvicola (Vittad.) Peck & Pun & Sathe \& Rahalkar 1976, Sathe \& Deshpande 1982 \\
\hline Agaricus vaporarius Schrank & Pun & Sathe \& Deshpande 1982 \\
\hline \multirow[t]{2}{*}{ Agaricus woodrowii Massee } & Pun & $\begin{array}{l}\text { Massee 1901, Woodrow 1903, Uppal et al. 1935, Manjula } \\
1983\end{array}$ \\
\hline & Pan & Thite \& Kulkarni 1976 \\
\hline Agaricus xanthodermus Genev. & Mah & Sathe \& Deshpande 1982 \\
\hline $\begin{array}{l}\text { Agaricus xantholepis (F.H. Møller) } \\
\text { F.H. Møller }\end{array}$ & Pun & Sathe \& Deshpande 1980 b \\
\hline $\begin{array}{l}\text { Chlorolepiota mahabaleshwarensis } \\
\text { Sathe \& S.D. Deshp. }\end{array}$ & Mah & $\begin{array}{l}\text { Sathe \& Deshpande 1979, Sathe \& Deshpande } 1980 \text { b, Sathe } \\
\text { \& Deshpande 1982; Massee 1901, Uppal et al } 1935 \text { as } \\
\text { Lepiota beckleri (Berk.) Sacc. }\end{array}$ \\
\hline \multirow[t]{3}{*}{$\begin{array}{l}\text { Chlorophyllum molybdites (G. Mey.) } \\
\text { Massee }\end{array}$} & Pun & $\begin{array}{l}\text { Sathe \& Rahalkar 1976, Sathe \& Deshpande 1980b, Sathe } \\
\text { \& Deshpande } 1982\end{array}$ \\
\hline & Kol & Patil \& Thite 1978 \\
\hline & Amr & Hedawoo 2010 \\
\hline Chlorophyllum rachodes (Vittad.) & Kol & Thite et al. 1976 as Lepiota rachodes (Vittad.) Quél. \\
\hline \multicolumn{3}{|l|}{ Vellinga } \\
\hline & Amr & Hedawoo 2010 as Macrolepiota rhacodes (Vittad.) Singer \\
\hline Chlorophyllum subrhacodes (Murrill) & Pun & Sathe \& Deshpande 1982 as Lepiota subrhacodes Murrill \\
\hline \multicolumn{3}{|l|}{ Vellinga } \\
\hline \multirow[t]{4}{*}{ Coprinus comatus (O.F. Müll.) Pers. } & Mum & Berkeley 1851, Uppal et al. 1935 \\
\hline & Nag & Trivedi 1972 \\
\hline & Pun & Sathe \& Rahalkar 1976, Sathe \& Deshpande 1982 \\
\hline & Amr & Hedawoo 2010 \\
\hline Coprinus fimetarius Fr. & Pun & Sathe \& Deshpande 1982 \\
\hline Lepiota alluviina (Peck) Morgan & Pun & Sathe \& Deshpande 1982 \\
\hline Lepiota amanitiformis Murrill & Pun & Sathe \& Deshpande 1982 \\
\hline Lepiota clypeolaria (Bull.) P. Kumm. & Pun & Sathe \& Rahalkar 1976 \\
\hline \multirow{2}{*}{ Lepiota cristata (Bolton) P. Kumm. } & Pun & Sathe \& Deshpande 1982 \\
\hline & Kol & Thite \& Patil 1982-83 \\
\hline Lepiota felina (Pers.) P. Karst. & Pun & Sathe \& Rahalkar 1976 \\
\hline
\end{tabular}




\begin{tabular}{|c|c|c|}
\hline Taxa & Distribution & References \\
\hline Lepiota naucinoides (Peck) Sacc. \& & Pun & Sathe \& Rahalkar 1975, Sathe \& Deshpande 1982 \\
\hline \multicolumn{3}{|l|}{ Trotter } \\
\hline Lepiota rugulosa Peck & Pun & Sathe \& Rahalkar 1975 \\
\hline Leucoagaricus americanus (Peck) & Pun & Sathe \& Rahalkar 1976, Sathe \& Deshpande 1982 as \\
\hline Vellinga & & Lepiota americana (Peck) Sacc. \\
\hline Leucoagaricus goossensiae (Beeli) & Kol & Patil \& Thite 1977 as Lepiota goossensiae Beeli \\
\hline \multicolumn{3}{|l|}{ Heinem. } \\
\hline $\begin{array}{l}\text { Leucoagaricus leucothites (Vittad.) } \\
\text { Wasser }\end{array}$ & Wasser & Trivedi 1972 as Lepiota naucina (Fr.) P. Kumm. \\
\hline \multicolumn{3}{|l|}{ Singer $\|$} \\
\hline \multirow{3}{*}{$\begin{array}{l}\text { Leucocoprinus badhamii (Berk. \& } \\
\text { Broome) Locq. }\end{array}$} & Pun & MCI 963 \\
\hline & Tha & $\begin{array}{l}\text { Uppal et al. } 1935 \text { as Lepiota badhamii (Berk. \& Broome) } \\
\text { Quél. }\end{array}$ \\
\hline & Mum & $\begin{array}{l}\text { Blatter } 1911 \text { as Leucoagaricus badhamii (Berk. \& Broome) } \\
\text { Singer }\end{array}$ \\
\hline Leucocoprinus cepistipes (Sowerby) & Mum & Uppal et al. 1935 as Lepiota sordescens (Berk. \& M.A. \\
\hline \multirow[t]{2}{*}{ Pat. } & Pun & $\begin{array}{l}\text { Curtis) Sacc. } \\
\text { Massee 1901, Uppal et al. 1935, Sathe \& Rahalkar 1975, } \\
1976 \text { as Lepiota caepastipes; Sathe \& Deshpande 1980b, } \\
\text { Sathe \& Deshpande } 1982 \text { as Leucocoprinus cepaestipes } \\
\text { (Sowerby) Pat. }\end{array}$ \\
\hline & Amr & Hedawoo 2010 as Leucocoprinus cepaestipes \\
\hline $\begin{array}{l}\text { Macrolepiota dolichaula (Berk. \& } \\
\text { Broome) Pegler \& R.W. Rayner }\end{array}$ & Pun & $\begin{array}{l}\text { Massee 1898, Woodrow 1903, Uppal et al. } 1935 \text { as Lepiota } \\
\text { altissima Massee }\end{array}$ \\
\hline Macrolepiota excoriata (Schaeff.) & Pun & Massee 1901 \\
\hline Wasser & Kol & $\begin{array}{l}\text { Uppal et al. 1935, Thite \& Patil 1982-83 as Lepiota } \\
\text { excoriata (Schaeff.) P. Kumm. }\end{array}$ \\
\hline Macrolepiota procera (Scop.) Singer" & Pun & Sathe \& Deshpande 1982 \\
\hline & Bhi & MCI 991 \\
\hline & Lon & MCI 952 \\
\hline & Amr & Hedawoo 2010 \\
\hline $\begin{array}{l}\text { Singerina indica Sathe \& S.D. Deshp. } \\
\text { Amanitaceae R. Heim ex Pouzar }\end{array}$ & Mah & Sathe \& Deshpande $1980 \mathrm{~b}$ \\
\hline $\begin{array}{l}\text { Amanita albofloccosa Sathe \& S.D. } \\
\text { Deshp. }\end{array}$ & Pun & Sathe \& Deshpande 1980 b \\
\hline $\begin{array}{l}\text { Amanita konkanensis P.G. Sathe \& } \\
\text { S.M. Kulk. }\end{array}$ & Pun & Kulkarni 1992 \\
\hline Amanita vaginata (Bull.) Lam. & Nag & Trivedi 1972 \\
\hline Amanita nauseosa (Wakef.) D.A. & Pun & Sathe \& Deshpande 1982 \\
\hline \multicolumn{3}{|l|}{ Reid } \\
\hline Amanita verna (Bull.) Lam. & Nag & Trivedi 1972 \\
\hline Limacella illinita (Fr.) Maire & Pun & $\begin{array}{l}\text { Sathe \& Rahalkar 1976, Sathe \& Deshpande } 1982 \text { as } \\
\text { Lepiota illinita (Fr.) Quél. }\end{array}$ \\
\hline \multicolumn{3}{|l|}{ Auriscalpiaceae Maas Geest. } \\
\hline $\begin{array}{l}\text { Lentinellus cochleatus (Pers.) P. Karst } \\
\text { Bolbitiaceae Singer }\end{array}$ & Nag & Trivedi 1972 as Lentinus cochleatus (Pers.) Fr. \\
\hline \multicolumn{3}{|l|}{ Massee } \\
\hline Conocybe pubescens (Gillet) Kühner" & Mah & Sathe \& Deshpande 1980 b \\
\hline & Mah & AMH 9244 \\
\hline Conocybe tenera (Schaeff.) Fayod & Pun & Sathe \& Rahalkar 1975, Sathe \& Deshpande 1982 \\
\hline & Mah & $\begin{array}{l}\text { Narendra \& Rao } 1976 \text { as Galera tenera (Schaeff.) P. } \\
\text { Kumm. }\end{array}$ \\
\hline Conocybe rickeniana P.D. Orton & Pun & $\begin{array}{l}\text { Sathe \& Rahalkar 1975, Sathe \& Deshpande } 1982 \text { as } \\
\text { Galerina teneroides [Galera teneroides (Peck) Sacc.] }\end{array}$ \\
\hline $\begin{array}{l}\text { Cantharellaceae J. Schröt. } \\
\text { Cantharellus violicolor Corner } \\
\text { Cortinariaceae R. Heim ex Pouzar }\end{array}$ & Sat & Chavan \& Barge 1977 \\
\hline
\end{tabular}




\begin{tabular}{|c|c|c|}
\hline Taxa & Distribution & References \\
\hline $\begin{array}{l}\text { Cortinarius graminicola Sathe \& S.D. } \\
\text { Deshp. }\end{array}$ & Pur & $\begin{array}{l}\text { Sathe \& Deshpande 1980b as Cortinarius graminicolus } \\
\text { Sathe \& S.D. Deshp. }\end{array}$ \\
\hline $\begin{array}{l}\text { Cortinarius fluorescens } \text { E. Horak } \\
\text { Entolomataceae Kotl. \& Pouzar }\end{array}$ & Pur & Sathe \& Deshpande 1982 \\
\hline $\begin{array}{l}\text { Entoloma brassicolens (D.A. Reid) } \\
\text { Noordel. }\end{array}$ & Mah & $\begin{array}{l}\text { Sathe \& Deshpande } 1982 \text { as Nolanea brassicolens D.A. } \\
\text { Reid }\end{array}$ \\
\hline Entoloma byssisedum (Pers.) Donk & Pun & $\begin{array}{l}\text { Sathe \& Rahalkar 1975, Sathe \& Deshpande } 1982 \text { as } \\
\text { Claudopus byssisedus (Pers.) Gillet }\end{array}$ \\
\hline $\begin{array}{l}\text { Entoloma ochrospora Sathe \& S.M. } \\
\text { Kulk. }\end{array}$ & Saw & Sathe \& Kulkarni 1979 \\
\hline \multirow[t]{2}{*}{ Entoloma strictius (Peck) Sacc. } & Thu & $\begin{array}{l}\text { Sathe \& Rahalkar 1975; Sathe \& Deshpande } 1982 \text { as } \\
\text { Rhodophyllus strictior (Peck) Singer (as R. strictius) }\end{array}$ \\
\hline & Bas & $\begin{array}{l}\text { Sathe \& Rahalkar } 1976 \text { as Rhodophyllus strictior (Peck) } \\
\text { Singer (as R. strictus) }\end{array}$ \\
\hline \multicolumn{3}{|l|}{ Hydnangiaceae Gäum. \& C.W. Dodge } \\
\hline Laccaria amethystina Cooke & $\begin{array}{l}\text { Pun } \\
\text { Amr }\end{array}$ & $\begin{array}{l}\text { Sathe \& Deshpande } 1982 \\
\text { Hedawoo } 2010\end{array}$ \\
\hline \multicolumn{3}{|l|}{ Hygrophoraceae Lotsy } \\
\hline \multicolumn{3}{|l|}{ Clémençon } \\
\hline $\begin{array}{l}\text { Hygrocybe boriviliensis B.D. } \\
\text { Sharma, S.D. Deshp. \& S.G. } \\
\text { Pradhan }\end{array}$ & $\begin{array}{l}\text { Rad } \\
\text { Bor }\end{array}$ & $\begin{array}{l}\text { Patil \& Thite } 1977 \text { as Omphalina chrysophylla (Fr.) Murill } \\
\text { Sharma et al. } 1986\end{array}$ \\
\hline $\begin{array}{l}\text { Hygrocybe ceracea (Sowerby) P. } \\
\text { Kumm. }\end{array}$ & Pun & Sathe \& Sasangan 1977, Sathe \& Deshpande 1982 \\
\hline $\begin{array}{l}\text { Hygrocybe pratensis (Fr.) Murrill } \\
\text { Hygrophoropsidaceae Kühner }\end{array}$ & Nag & Trivedi 1972 as Hygrophorus pratensis (Fr.) Fr. \\
\hline $\begin{array}{l}\quad \text { Hygrophoropsis aurantiaca (Wulfen) } \\
\text { Maire } \\
\text { Inocybaceae Jülich }\end{array}$ & Amr & Hedawoo 2010 \\
\hline Crepidotus mollis (Schaeff.) Staude" & $\begin{array}{l}\text { Mah } \\
\text { Bhi } \\
\text { Mah }\end{array}$ & $\begin{array}{l}\text { Sathe \& Deshpande } 1980 \text { b } \\
\text { MCI } 912 \\
\text { AMH } 9243\end{array}$ \\
\hline \multicolumn{3}{|l|}{ Kumm. } \\
\hline & $\operatorname{Rad}$ & Patil \& Thite 1977 \\
\hline Inocybe cookei Bres. & Pun & Sathe \& Deshpande 1982 \\
\hline Inocybe dulcamara (Pers.) P. Kumm. & Pun & Sathe \& Deshpande 1982 as Inocybe delecta P. Karst. \\
\hline Inocybe griseolilacina J.E. Lange & Pun & Sathe \& Rahalkar 1976, Sathe \& Deshpande 1982 \\
\hline Inocybe infelix Peck & Pun & Sathe \& Deshpande 1982 \\
\hline Inocybe rimosa (Bull.) P. Kumm. & Pun & $\begin{array}{l}\text { Sathe \& Sasangan 1977, Sathe \& Deshpande } 1982 \text { as } \\
\text { Inocybe fastigiata (Schaeff.) Quél. }\end{array}$ \\
\hline \multicolumn{3}{|l|}{ Lyophyllaceae Jülich } \\
\hline Calocybe gambosa (Fr.) Donk & Nag & Trivedi 1972 as Tricholoma gambosum (Fr.) P. Kumm. \\
\hline $\begin{array}{l}\text { Calocybe indica Purkay. \& A. } \\
\text { Chandra }\end{array}$ & Chandra & Hedawoo 2010 \\
\hline Termitomyces clypeatus R. Heim & Kan & Patil et al. 1979 \\
\hline \multirow[t]{3}{*}{$\begin{array}{l}\text { Termitomyces eurrhizus (Berk.) R. } \\
\text { Heim }\end{array}$} & Mal & $\begin{array}{l}\text { Patil et al. } 1979 \text { as Termitomyces cartilaginous (Berk.) R. } \\
\text { Heim. }\end{array}$ \\
\hline & Pun & $\begin{array}{l}\text { Sathe \& Deshpande } 1980 \text { b as Termitomyces poonensis } \\
\text { Sathe \& S.D. Deshp. }\end{array}$ \\
\hline & Pun & MCI 977 \\
\hline \multirow[t]{2}{*}{ Termitomyces heimii Natarajan } & Pun & $\begin{array}{l}\text { Patil et al. } 1979 \text { as Termitomyces albuminosus (Berk.) R. } \\
\text { Heim }\end{array}$ \\
\hline & Amr & Hedawoo 2010 \\
\hline \multirow[t]{4}{*}{ Termitomyces mammiformis R. Heim } & Kol & Thite et al. 1976 \\
\hline & $\operatorname{Rad}$ & Patil \& Thite 1977 \\
\hline & Pun & Patil et al. 1979 \\
\hline & Amr & Hedawoo 2010 \\
\hline
\end{tabular}




\begin{tabular}{|c|c|c|}
\hline Taxa & Distribution & References \\
\hline \multirow[t]{2}{*}{$\begin{array}{l}\text { Termitomyces microcarpus (Berk. \& } \\
\text { Broome) R. Heim } \|\end{array}$} & Pun & Patil et al. 1979 \\
\hline & Pun & MCI 976 \\
\hline \multirow{2}{*}{\multicolumn{3}{|c|}{ Heim }} \\
\hline & & \\
\hline \multicolumn{3}{|l|}{ Marasmiaceae Roze ex Kühner } \\
\hline \multirow[t]{3}{*}{$\begin{array}{l}\text { Anthracophyllum nigritum (Lév.) } \\
\text { Kalchbr. }\end{array}$} & Kha & Bhide et al. 1987 \\
\hline & Mah & АMH 9240, 9268 \\
\hline & Mul & MCI 933 \\
\hline $\begin{array}{l}\text { Anthracophyllum lateritium (Berk. \& } \\
\text { M.A. Curtis) Singer }\end{array}$ & Kha & $\begin{array}{l}\text { Theissen 1911, Uppal et al } 1935 \text { as Xerotus lateritius Berk. } \\
\text { \& M.A. Curtis }\end{array}$ \\
\hline Atheniella aurantiidisca (Murrill) & Kol & Thite \& Patil 1982-83 as Mycena aurantiidisca (Murrill) \\
\hline $\begin{array}{l}\text { Redhead, Moncalvo, Vilgalys, Desjardin } \\
\text { \& B.A. Perry }\end{array}$ & & Murrill \\
\hline $\begin{array}{l}\text { Gymnopus androsaceus (L.) J.L. } \\
\text { Mata \& R.H. Petersen }\end{array}$ & Mah & $\begin{array}{l}\text { Sathe \& Deshpande } 1982 \text { as Marasmius androsaceus (L.) } \\
\text { Fr. }\end{array}$ \\
\hline Gymnopus fusipes (Bull.) Gray & $\operatorname{Rad}$ & $\begin{array}{l}\text { Thite et al. 1976, Patil \& Thite } 1977 \text { as Collybia fusipes } \\
\text { (Bull.) Quél. }\end{array}$ \\
\hline Marasmius echinosphaerus Singer & Bhi & Sathe \& Deshpande 1982 \\
\hline \multirow[t]{2}{*}{ Marasmius goossensiae Beeli } & $\operatorname{Rad}$ & Patil \& Thite 1977 \\
\hline & Kol & Patil \& Thite 1978 \\
\hline Marasmius gordipes Sacc. \& Paol. & Pun & Sathe \& Deshpande 1982 \\
\hline \multirow[t]{2}{*}{ Marasmius graminum (Lib.) Berk. } & $\operatorname{Rad}$ & Patil \& Thite 1977 \\
\hline & Kol & Patil \& Thite 1978 \\
\hline \multirow[t]{2}{*}{ Fr. ${ }^{\text {Marasmius haematocephalus (Mont.) }}$} & $\operatorname{Rad}$ & Patil \& Thite 1977 \\
\hline & Pun & MCI 945 \\
\hline \multirow[t]{2}{*}{ Marasmius oreades (Bolton) Fr. } & Pun & Sathe \& Rahalkar 1975 as Scorteus oreades (Fr.) anon. \\
\hline & Bor & Sathe \& Deshpande 1982 as Scorteus oreades (Fr.) anon. \\
\hline Marasmius rhizophilus (V. Brig.) Fr. & $\mathrm{Amb}$ & Patil 1978, Patil \& Thite 1978 \\
\hline \multirow[t]{3}{*}{ Marasmius rotula (Scop.) Fr. } & Pun & Sathe \& Sasangan 1977 \\
\hline & Bor & Sathe \& Deshpande 1982 \\
\hline & Amr & Hedawoo 2010 \\
\hline \multirow[t]{3}{*}{ Marasmius siccus (Schwein.) Fr. } & Nag & Trivedi 1972 \\
\hline & Pun & Sathe \& Rahalkar 1975, 1976 \\
\hline & Mah & Sathe \& Deshpande 1982 \\
\hline Marasmius spaniophyllus Berk. & Kha & Theissen 1911, Uppal et al. 1935 \\
\hline Marasmius thwaitesii Berk. \& & Pun & Sathe \& Deshpande 1982 \\
\hline \multicolumn{3}{|l|}{ Broome } \\
\hline Marasmius tubulatus Petch & Pun & Sathe \& Deshpande 1982 \\
\hline \multirow[t]{2}{*}{ Marasmius umbrinus Pegler } & $\operatorname{Rad}$ & Patil \& Thite 1977 \\
\hline & Kol & Patil \& Thite 1978 \\
\hline Megacollybia platyphylla (Pers.) & Kol & Patil \& Thite 1978 as Collybia platyphylla (Pers.) P. Kumm. \\
\hline Kotl. \& Pouzar & & \\
\hline $\begin{array}{l}\text { Trogia grisea (Berk.) Pat. } \\
\text { Mycenaceae Overeem }\end{array}$ & Kha & Uppal et al. 1935 as Xerotus griseus Berk. \\
\hline Mycena avenacea (Fr.) Quél. & Nag & Trivedi 1972 \\
\hline Mycena galericulata (Scop.) Gray & Kol & Thite \& Patil 1982-83 \\
\hline Mycena galopus (Pers.) P. Kumm. & Kol & Thite \& Patil 1982-83 as Mycena leucogala (Cooke) Sacc. \\
\hline Mycena juncicola (Fr.) Gillet & Mum & Sathe \& Deshpande 1982 \\
\hline Mycena madronicola A.H. Sm. & Kha & Sathe \& Deshpande 1982 \\
\hline Mycena mисor (Batsch) Quél. & Mah & Sathe \& Deshpande 1982 \\
\hline Mycena stylobates (Pers.) P. Kumm. & Mah & Sathe \& Deshpande 1982 \\
\hline Mycena subcaerulea (Peck) Sacc. & Pun & Sathe \& Rahalkar 1975, Sathe \& Deshpande 1982 \\
\hline Panellus belangeri (Mont.) Singer & Nag & Graham 1915 as Trogia belangeri (Mont.) Fr. \\
\hline Panellus ringens (Fr.) Romagn. & Pun & $\begin{array}{l}\text { Sathe \& Rahalkar } 1975 \text {, Sathe \& Deshpande } 1982 \text { as } \\
\text { Scytinotus ringens (Fr.) P. Karst. }\end{array}$ \\
\hline Physalacriaceae Corner & & \\
\hline
\end{tabular}




\begin{tabular}{|c|c|c|}
\hline Taxa & Distribution & References \\
\hline Armillaria tabescens (Scop.) Emel & Pun & $\begin{array}{l}\text { Sathe \& Rahalkar 1975, Sathe \& Deshpande } 1982 \text { as } \\
\text { Clitocybe monadelpha (Morgan) Sacc. }\end{array}$ \\
\hline \multirow[t]{4}{*}{$\begin{array}{l}\text { Hymenopellis radicata (Relhan) R.H. } \\
\text { Petersen }\end{array}$} & Kar & $\begin{array}{l}\text { Sathe \& Rahalkar 1976, Sathe \& Deshpande } 1982 \text { as } \\
\text { Oudemansiella radicata (Relhan) Singer; Sathe \& Rahalkar } \\
1976 \text { as Collybia radicata (Relhan) Quél. }\end{array}$ \\
\hline & Thu & $\begin{array}{l}\text { Sathe \& Rahalkar } 1976 \text { as Oudemansiella radicata (Relhan) } \\
\text { Singer }\end{array}$ \\
\hline & Lon & MCI 961 \\
\hline & Bhi & MCI 963 \\
\hline $\begin{array}{l}\text { Oudemansiella indica Sathe \& S.D. } \\
\text { Deshp. }\end{array}$ & Kan & Sathe \& Deshpande 1980b \\
\hline $\begin{array}{l}\text { Oudemansiella mucida (Schrad.) } \\
\text { Höhn. }\end{array}$ & Nag & Trivedi 1972 as Armillaria mucida (Schrad.) P. Kumm. \\
\hline $\begin{array}{l}\quad \text { Rhizomarasmius undatus (Berk.) R.H. } \\
\text { Petersen } \\
\text { Pleurotaceae Kühner }\end{array}$ & Pun & $\begin{array}{l}\text { Sathe \& Rahalkar 1976, Sathe \& Deshpande } 1982 \text { as } \\
\text { Marasmius undatus (Berk.) Fr. }\end{array}$ \\
\hline Pleurotus columbinus Quél. & Pun & Sathe \& Deshpande $1980 \mathrm{~b}$ \\
\hline Pleurotus cornucopiae (Paulet) & Sat & Chavan \& Barge 1977 as Pleurotus sapidus Sacc. \\
\hline \multicolumn{3}{|l|}{ Rolland } \\
\hline Pleurotus dryinus (Pers.) P. Kumm. & $\begin{array}{l}\text { Sat } \\
\text { Amr }\end{array}$ & $\begin{array}{l}\text { Chavan \& Barge } 1977 \\
\text { Hedawoo } 2010\end{array}$ \\
\hline Pleurotus flabellatus Sacc." & $\begin{array}{l}\text { Pun } \\
\text { Mul }\end{array}$ & $\begin{array}{l}\text { Sathe \& Deshpande 1980b, Sathe \& Deshpande } 1982 \\
\text { MCI } 897\end{array}$ \\
\hline Pleurotus membranaceus Massee & Pan & $\begin{array}{l}\text { Massee } 1901 \text {, Woodrow 1903, Uppal et al. 1935, Thite \& } \\
\text { Kulkarni } 1976 \\
\text { Uppal et al. } 1935\end{array}$ \\
\hline Pleurotus ostreatus (Jacq.) P. Kumm. & $\begin{array}{l}\text { Pan } \\
\text { Kar } \\
\text { Amr }\end{array}$ & $\begin{array}{l}\text { Sathe \& Rahalkar } 1975 \\
\text { Vaidya et al. } 1991 \\
\text { Hedawoo } 2010\end{array}$ \\
\hline $\begin{array}{l}\text { Hohenbuehelia petaloides (Bull.) } \\
\text { Schulzer }\end{array}$ & Amr & Hedawoo 2010 as Pleurotus petaloides (Bull.) Quél. \\
\hline $\begin{array}{l}\quad \text { Hohenbuehelia spathulata (Pers.) } \\
\text { Singer } \\
\text { Pluteaceae Kotl. \& Pouzar }\end{array}$ & Sat & Chavan \& Barge 1977 as Pleurotus spathulatus (Pers.) Peck \\
\hline Pluteus cervinus (Schaeff.) P. Kumm. & Pun & $\begin{array}{l}\text { Sathe \& Deshpande 1982; Sathe \& Deshpande 1980b as } \\
\text { Pluteus atricapillus (Batsch) Fayod }\end{array}$ \\
\hline Pluteus nanus (Pers.) P. Kumm. & Nag & Trivedi 1972 \\
\hline $\begin{array}{l}\text { Volvopluteus earlei (Murrill) Vizzini, } \\
\text { Contu \& Justo }\end{array}$ & Amr & Hedawoo 2010 as Volveriella media (Schumach.) Singer \\
\hline $\begin{array}{l}\quad \text { Volvopluteus gloiocephalus (DC.) } \\
\text { Vizzini, Contu \& Justo } \\
\text { Polyporaceae Fr. Ex Corda }\end{array}$ & Kol & Patil \& Thite 1978 as Volvariella speciosa (Fr.) Singer \\
\hline $\begin{array}{l}\text { Lentinus alpacus Senthil. \& S.K. } \\
\text { Singh }^{\#}\end{array}$ & Pun & Senthilarasu \& Singh 2012 \\
\hline Lentinus connatus Berk. & Mum & $\begin{array}{l}\text { Pegler 1983; Lévillé } 1846 \text { as Lentinus revelatus Berk.; } \\
\text { Lévillé 1846, Uppal et al. } 1935 \text { as Lentinus javanicus Lév }\end{array}$ \\
\hline Lentinus polychrous Lév. & Nag & Pegler 1983 \\
\hline Lentinus squarrosulus Mont. & Pun & $\begin{array}{l}\text { Pegler } 1983 \text { (specimen deposited at Kew in } 1977 \text { by } \\
\text { Sasangan, AMH 3655) }\end{array}$ \\
\hline & Kha & $\begin{array}{l}\text { Theissen } 1911 \text { as Lentinus aff. subnudus Berk.; Uppal et al. } \\
1935 \text { as Lentinus subnudus Berk. }\end{array}$ \\
\hline \multirow[t]{4}{*}{$\begin{array}{l}\text { Coprinellus micaceus (Bull.) } \\
\text { Vilgalys, Hopple \& Jacq. } \\
\text { Johnson }\end{array}$} & Nag & Trivedi 1972 as Coprinus micaceus (Bull.) Fr. \\
\hline & Pun & $\begin{array}{l}\text { Sathe \& Rahalkar 1975, Sathe \& Deshpande } 1982 \text { as } \\
\text { Coprinus micaceus (Bull.) Fr. }\end{array}$ \\
\hline & Kol & Thite et al. 1976 as Coprinus micaceus (Bull.) Fr. \\
\hline & $\operatorname{Rad}$ & Patil \& Thite 1977 \\
\hline
\end{tabular}




\begin{tabular}{|c|c|c|}
\hline Taxa & Distribution & References \\
\hline $\begin{array}{l}\text { Coprinellus disseminates (Pers.) J.E. } \\
\text { Lange }\end{array}$ & Pun & $\begin{array}{l}\text { Sathe \& Rahalkar 1975, Sathe \& Deshpande } 1982 \text { as } \\
\text { Pseudocoprinus disseminatus (Pers.) Kühner }\end{array}$ \\
\hline $\begin{array}{l}\text { Coprinellus ephemerus (Bull.) } \\
\text { Redhead, Vilgalys \& Moncalvo }\end{array}$ & Mah & $\begin{array}{l}\text { Sathe \& Rahalkar 1975, Sathe \& Deshpande } 1980 \mathrm{~b} \text { as } \\
\text { Ephemerocybe ephemerus (Fr.) Fayod }\end{array}$ \\
\hline & Pun & $\begin{array}{l}\text { Sathe \& Deshpande } 1982 \text { as Ephemerocybe ephemerus (Fr.) } \\
\text { Fayod }\end{array}$ \\
\hline $\begin{array}{l}\text { Coprinopsis nivea (Pers.) Redhead, } \\
\text { Vilgalys \& Moncalvo }\end{array}$ & Pun & Narendra \& Rao 1976 as Coprinus niveus (Pers.) Fr. \\
\hline $\begin{array}{l}\text { Coprinopsis radiata (Bolton) } \\
\text { Redhead, Vilgalys \& Moncalvo }\end{array}$ & Pun & Narendra \& Rao 1976 as Coprinus radiatus (Bolton) Gray \\
\hline $\begin{array}{l}\text { Cystoagaricus trisulphuratus (Berk.) } \\
\text { Singer }\end{array}$ & Pun & Sathe \& Deshpande 1982 \\
\hline $\begin{array}{l}\text { Ephemerocybe poonensis Sathe \& } \\
\text { S.D. Deshp. }\end{array}$ & $\begin{array}{l}\text { Mul } \\
\text { Pun }\end{array}$ & $\begin{array}{l}\text { MCI } 832 \\
\text { Sathe \& Deshpande 1980b }\end{array}$ \\
\hline $\begin{array}{l}\text { Lacrymaria lacrymabunda (Bull.) } \\
\text { Pat. }\end{array}$ & Nag & Trivedi 1972 as Hypholoma velutinum (Pers.) P. Kumm. \\
\hline $\begin{array}{l}\text { Parasola setulosa (Berk. \& Broome) } \\
\text { Redhead, Vilgalys \& Hopple }\end{array}$ & Kol & $\begin{array}{l}\text { Thite \& Patil 1982-83 as Coprinus setulosus Berk. \& } \\
\text { Brooome }\end{array}$ \\
\hline Psathyrella candolleana (Fr.) Maire"l & Pun & $\begin{array}{l}\text { Sathe \& Rahalkar } 1976 \text { as Hypholoma appendiculatum } \\
\text { (Bull.) Quél. } \\
\text { MCI } 941\end{array}$ \\
\hline Psathyrella nana (Massee) Manjula & Pun & $\begin{array}{l}\text { Manjula 1983; Massee 1901, Uppal et al. } 1935 \text { as Psathyra } \\
\text { nana Massee }\end{array}$ \\
\hline $\begin{array}{l}\quad \text { Psathyrella poonensis Sathe \& S.D. } \\
\text { Deshp. } \\
\text { Russulaceae Lotsy }\end{array}$ & Pun & Sathe \& Deshpande 1980b \\
\hline Lactarius deliciosus (L.) Gray & Kol & Patil \& Thite 1978 \\
\hline Russula claroflava Grove & Amr & Hedawoo 2010 \\
\hline Schizophyllaceae Quél & & \\
\hline Schizophyllum commune Fr. $\|$ & Mum & $\begin{array}{l}\text { Theissen 1911, Uppal et al. } 1935 \text { as Schizophyllum alneum } \\
\text { (L.) J. Schröt. }\end{array}$ \\
\hline & Pan & $\begin{array}{l}\text { Thite \& Kulkarni 1976; Thite \& Kulkarni } 1976 \text { as } \\
\text { Schizophyllum alneum (L.) J. Schröt. }\end{array}$ \\
\hline & Kha & Uppal et al. 1935 \\
\hline & Pun & Sathe \& Deshpande 1982 \\
\hline & Mul & MCI 915 \\
\hline & Amr & Hedawoo 2010 \\
\hline Strophariaceae Singer \& A. H. Sm. & & \\
\hline Agrocybe broadwayi (Murrill) Dennis & $\begin{array}{l}\text { Kol } \\
\text { Rad }\end{array}$ & $\begin{array}{l}\text { Thite et al. } 1976 \\
\text { Patil \& Thite } 1977\end{array}$ \\
\hline Agrocybe pediades (Fr.) Fayod & Pun & $\begin{array}{l}\text { Sathe \& Rahalkar 1975, Sathe \& Deshpande } 1982 \text { as } \\
\text { Naucoria semiorbicularis (Bull.) Quél. }\end{array}$ \\
\hline Gymnopilus karnalensis S.M. Kulk. & Kar & Kulkarni 1990 \\
\hline Hebeloma albidulum Peck & Pun & Sathe \& Rahalkar 1975 \\
\hline Hebeloma fastibile (Pers.) P. Kumm. & Mum & Sathe \& Deshpande 1982 \\
\hline Hebeloma vatricosum (Fr.) Murrill & Pun & $\begin{array}{l}\text { Sathe \& Deshpande } 1982 \text { as Inocybe vatricosa (Fr.) P. } \\
\text { Karst. }\end{array}$ \\
\hline Hemipholiota populnea (Pers.) Bon & Sat & Chavan \& Barge 1977 as Pholiota destruens (Brond.) Gillet \\
\hline Pachylepyrium fulvidula (Singer) & Pun & Sathe \& Rahalkar 1975 as Pachylepyrium fulvidulum; Sathe \\
\hline Singer & & \& Deshpande 1982 as Pachylepyrium fulvida \\
\hline Pholiota indica Massee & Pun & Massee 1901, Uppal et al. 1935, Sathe \& Deshpande 1982 \\
\hline $\begin{array}{l}\text { Pholiota mahabaleshwarensis Sathe } \\
\text { \& S.D. Deshp. }\end{array}$ & Mah & Sathe \& Deshpande 1980a, Sathe \& Deshpande 1980b \\
\hline $\begin{array}{l}\text { Pholiota squarrosoadiposa J. E. } \\
\text { Lange }\end{array}$ & Sat & Chavan \& Barge 1977 \\
\hline Psilocybe merdaria (Fr.) Ricken & Pun & $\begin{array}{l}\text { Massee 1901, Uppal et al. } 1935 \text { as Stropharia merdaria } \\
\text { (Fr.) Quél. }\end{array}$ \\
\hline $\begin{array}{l}\text { Psilocybe semilanceata (Fr.) P. } \\
\text { Kumm. }\end{array}$ & Pun & Sathe \& Sasangan 1977, Sathe \& Deshpande 1982 \\
\hline
\end{tabular}




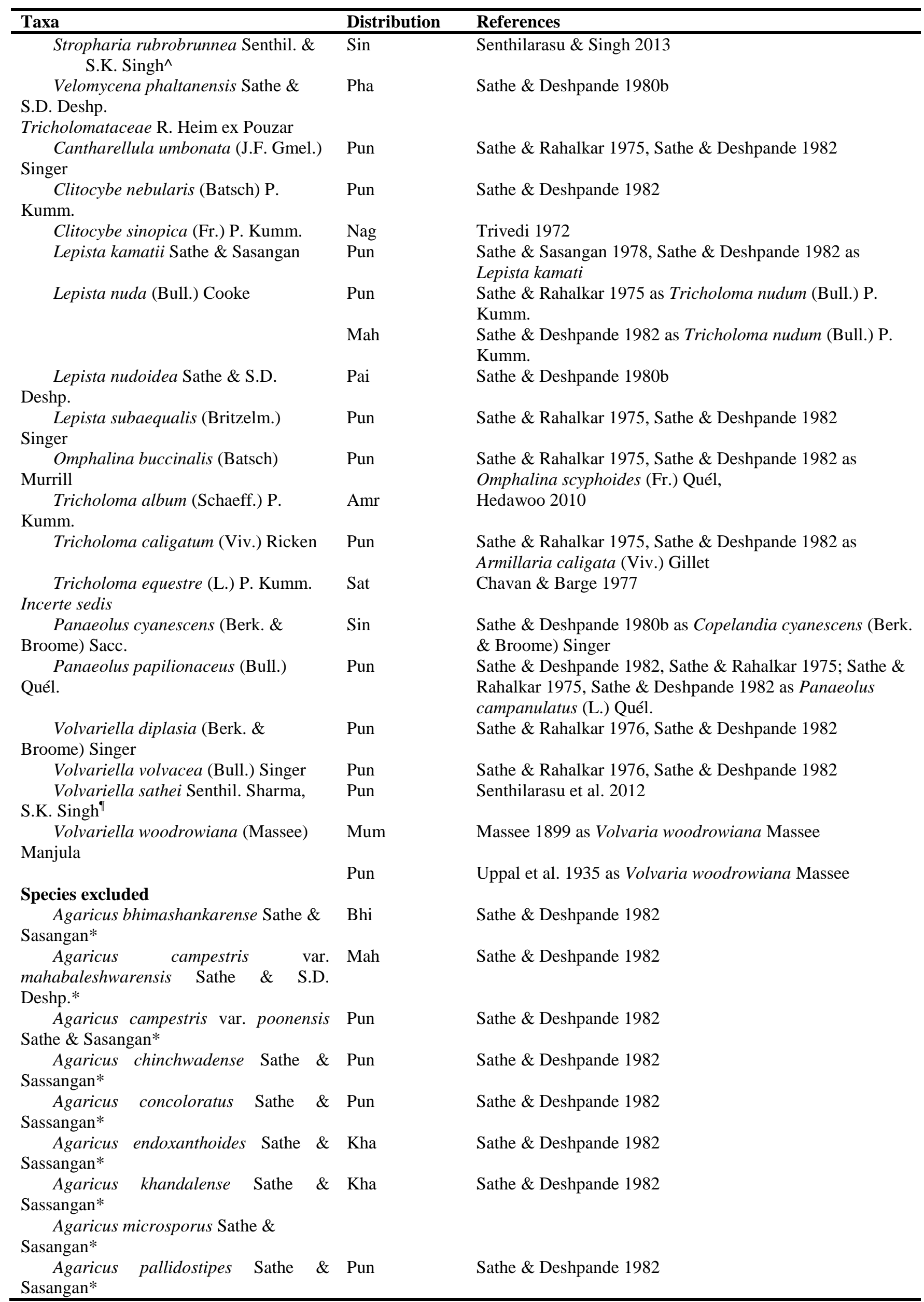




\begin{tabular}{|c|c|c|}
\hline Taxa & Distribution & References \\
\hline Agaricus pathakii Sathe \& Sasangan* & Pun & Sathe \& Deshpande 1982 \\
\hline Agaricus subglobosporus Sathe \& & Pun & Sathe \& Deshpande 1982 \\
\hline Sasangan* & & \\
\hline $\begin{array}{l}\text { Agaricus sylvaticus var. minor Sathe } \\
\text { \& Sasangan* }\end{array}$ & Pun & Sathe \& Deshpande 1982 \\
\hline $\begin{array}{l}\text { Agaricus xanthodermus var. } \\
\text { poonensis } \text { Sathe \& Sasangan* }\end{array}$ & Pun & Sathe \& Deshpande 1982 \\
\hline $\begin{array}{l}\text { Agarocybe poonensis Sathe \& } \\
\text { Sasangan* }\end{array}$ & Pun & Sathe \& Deshpande 1982 \\
\hline $\begin{array}{l}\text { Calocybe khandalensis Sathe \& } \\
\text { Sasangan* }\end{array}$ & Kha & Sathe \& Deshpande 1982 \\
\hline $\begin{array}{l}\text { Clitocybe mahabaleshwarensis Sathe } \\
\text { \& S.D. Deshp. * }\end{array}$ & Mah & Sathe \& Deshpande 1982 \\
\hline $\begin{array}{l}\text { Copelandia cyanescens var. } \\
\text { mahabaleshwarensis Sathe \& S.D. } \\
\text { Deshp.* }\end{array}$ & Mah & Sathe \& Deshpande 1982 \\
\hline $\begin{array}{l}\text { Flammula mahabaleshwarensis Sathe } \\
\text { \& S.D. Deshp. * }\end{array}$ & Mah & Sathe \& Deshpande 1982 \\
\hline $\begin{array}{l}\text { Galerina poonensis Sathe \& } \\
\text { Sasangan* }\end{array}$ & Pun & Sathe \& Deshpande 1982 \\
\hline $\begin{array}{c}\text { Hypholoma appendiculatum var. } \\
\text { poonensis Sathe \& Rahalkar* }\end{array}$ & Pun & Sathe \& Deshpande 1982 \\
\hline Inocybe indica Sathe \& Sasangan* & Pun & $\begin{array}{l}\text { Sathe \& Deshpande } 1982-\text { Nom. illegit. Art. } 53.1 \text { a } \\
\text { homonym of Inocybe indica Sarwal }\end{array}$ \\
\hline $\begin{array}{l}\text { Inocybe poonensis Sathe \& } \\
\text { Sasangan* }\end{array}$ & Pun & Sathe \& Deshpande 1982 \\
\hline Lepiota bosii Sathe \& Rahalkar* & Pun & Sathe \& Rahalkar 1976, Sathe \& Deshpande 1982 \\
\hline $\begin{array}{l}\text { Lepiota sanguinea Sathe \& } \\
\text { Deshpande }{ }^{\nabla}\end{array}$ & Pha & $\begin{array}{l}\text { Sathe \& Deshpande } 1980 \mathrm{~b}-\text { Nom. illegit. Art. } 53.1 \text { a } \\
\text { homonym of Lepiota sanguinea Beeli (current name } \\
\text { Leucoagaricus sanguineus (Beeli) Heinem. }\end{array}$ \\
\hline $\begin{array}{l}\text { Leucocoprinus kamatii Sathe \& } \\
\text { Sasangan* }\end{array}$ & Pun & Sathe \& Deshpande 1982 \\
\hline $\begin{array}{l}\text { Leucopaxillus kamatii Sathe \& } \\
\text { Rahalkar* }\end{array}$ & Pun & Sathe \& Deshpande 1982 \\
\hline $\begin{array}{l}\text { Pholiota squarrosoides var. } \\
\text { mahabaleshwarensis Sathe \& } \\
\text { S.D. Deshp. }\end{array}$ & Mah & Sathe \& Deshpande 1982 \\
\hline $\begin{array}{l}\text { Pleurotus poonensis Sathe \& } \\
\text { Sasangan* }\end{array}$ & Pun & Sathe \& Deshpande 1982 \\
\hline $\begin{array}{l}\text { Podabrella poonensis Sathe \& } \\
\text { Sasangan* }\end{array}$ & Pun & Sathe \& Deshpande 1982 \\
\hline Pluteus tropica Sathe \& Rahalkar* & Pun & Sathe \& Deshpande 1982 \\
\hline Ripartites munjali Sathe \& Rahalkar* & Pun & Sathe \& Deshpande 1982 \\
\hline Stropharia singeri Sathe \& Rahalkar* & Pun & Sathe \& Deshpande 1982 \\
\hline $\begin{array}{l}\text { Volvariella deodikarii Sathe \& } \\
\text { Rahalkar* }\end{array}$ & Pun & Sathe \& Deshpande 1982 \\
\hline
\end{tabular}

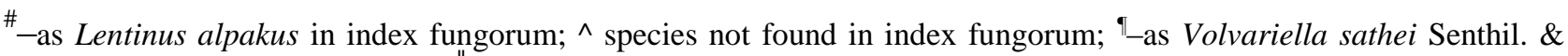

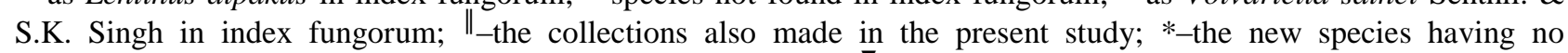
description and not validly published (nom. inval./nom. nudum); ${ }^{\nabla}$-homonym (nom. illegit.).

The most represented genus is Agaricus (18 spp.) followed by Marasmius (13 spp.), Mycena (8 spp.), Lepiota (7 spp.), Pleurotus, Termitomyces (6 spp. each) and Amanita, Inocybe (5 spp. each). Most of the genera are represented by one or two species.

The Kerala state has been well explored for its agaric diversity and 616 species of gilled mushrooms belonging to 112 genera have been reported (Farook et al. 2013). A total of 138 new species have been described from Kerala State, whereas, only 21 new species and two new genera (Singerina and Chlorolepiota) have been reported from Maharashtra though the State has dense forest areas. The present study indicates that less number of species have been reported from 

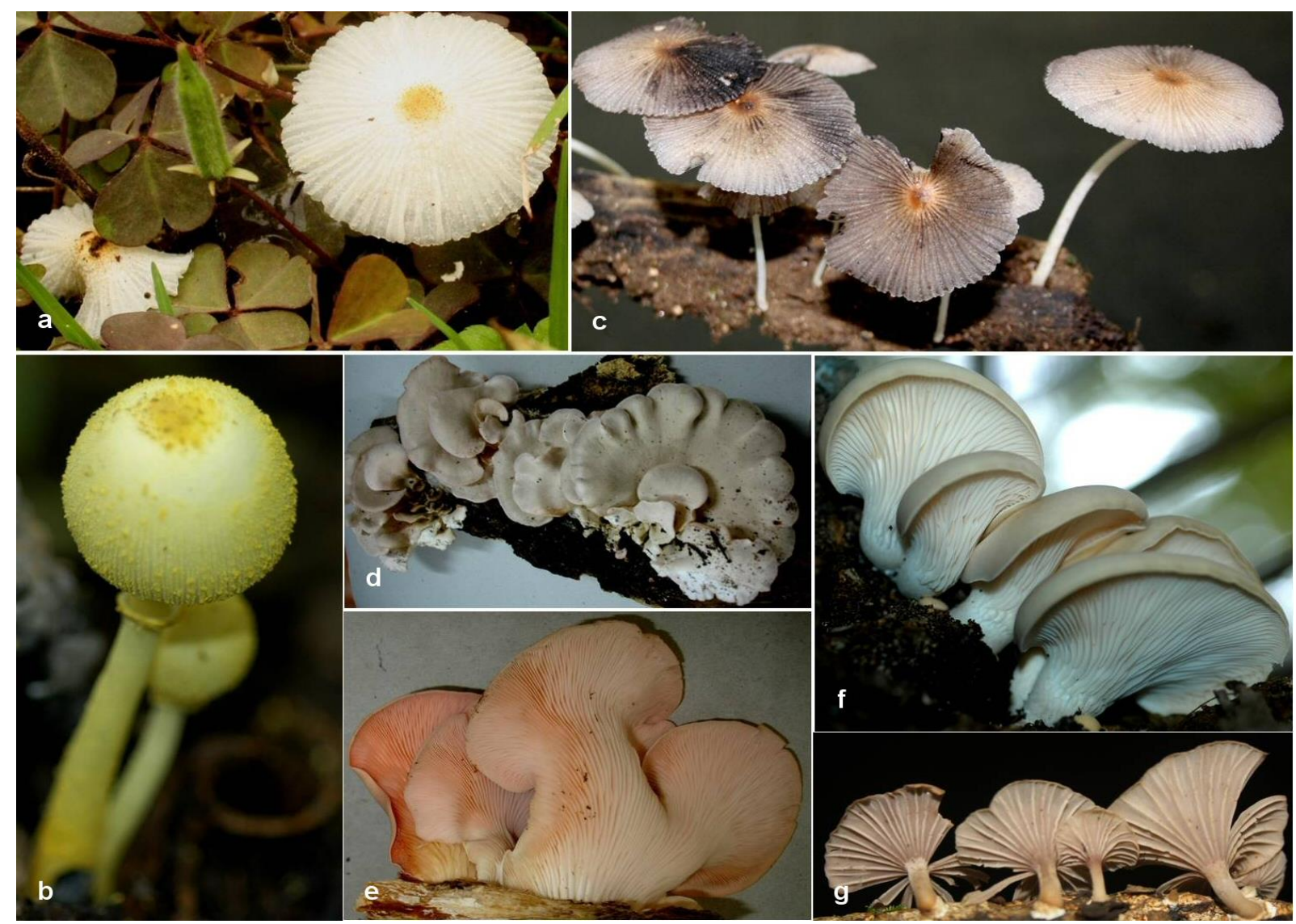

Fig. 4 - a, Leucocoprinus fragilissimus, basidiomes under natural conditions in ARI campus. b, Leucocoprinus birnbaumii basidiomes under natural conditions in Pune University campus. c, Parasola plicatilis, basidiomes under natural conditions in ARI campus. d, e Pleurotus djmor. d, surface view. e, gill view. f, Pleurotus cystidiosus, basidiomes under natural conditions in ARI campus. g, Trogia infundibuliformis, basdiomes under natural conditions in Mahabaleshwar.

Maharashtra that reflects insufficient study. The most of the species listed were published between the period of Massee 1901 and 1992. Since then apparently, there was no report on the taxonomy and diversity of gilled fungi occurring in Maharashtra. Many parts of the state have not been surveyed and even dense forests in Western Ghats and Vidarbha region have not been adequately explored. A total of 26 new species and 7 new varieties published that are lacking descriptions and illustrations (Sathe \& Deshpande 1982) and a properly described, homonym Lepiota sanguinea (Sathe \& Deshpande 1980b) are excluded. However, the specimens have been well preserved at $\mathrm{AMH}$ and all the species will be phylogenetically analysed in future.

\section{Acknowledgements}

The major part of the work was carried out at Agharkar Research Institute, Pune. I sincerely thank Mr. Santosh Swami, Mr. Subash Gaikwad, Mrs. Vimal Waingankar and Dr. Rajesh Kumar $\mathrm{KC}$ for their assistance in field trips. All the library staff of ARI is greatly acknowledged. Sincere thanks are extended to the former Directors, Dr. VS Rao and Dr. PP Kanekar, ARI for the laboratory facilities provided and Department of Science \& Technology, Govt. of India for the financial assistance.

\section{References}

Bas C. 1969 - Morphology and subdivision of Amanita and a monograph on its section Lepidella. Persoonia 5: 285-579. 
${ }^{\Psi}$ Berkeley MJ. 1851 - Decades XXXII, XXXIII, Sikkim Himalayan Fungi collected by Dr. JD Hooker: Hooker Journal of Botany 3, 39-49.

Bhide VP, Pande A, Sathe AV, Rao VG, Patwardhan PG. 1987 - Fungi of Maharashtra (Supplement-I). Maharashtra Association for the Cultivation of Science, Research Institute, Pune $146 \mathrm{p}$.

${ }^{\Psi}$ Blatter E. 1911 - A list of Indian fungi, chiefly of the Bombay Presidency, with the description of two new species. Journal of Bombay Natural History Society 21, 146-152.

Chavan PB, Barge SN. 1977 - Some fleshy fungi from Maharashtra. Botanique 8, 124-128.

Corner EJH, Bas C. 1962 - The genus Amanita in Singapore and Malaya. Persoonia 2: 241-304.

Farook AV, Khan SS, Manimohan P. 2013 - A checklist of agarics (gilled mushrooms) of Kerala State, India. Mycosphere 4(1), 97-131. http://dx.doi.org/10.5943/mycosphere/4/1/6

${ }^{\Psi}$ Graham RJD. 1915 - Report of the Economic Botanist. In: Report of Agricultural College of Nagpur of Botanical and Chemical Research etc. Department of Agriculture, Central Provinces and Bihar, for the year 1914-15 (Nagpur: Government Press) 11-17.

Hedawoo GB. 2010 - Wild mushroom flora from Amravati Regoin, Maharastra, India. Journal of Mycology and Plant Pathology 40(3): 441-444.

Hedawoo GB, Mohite PU. 2008 - Some wild edible mushrooms from Melghat Tiger Reserve Forest and Amravati Region. Bioscience Biotechnology Research Communications 1(2), 163-167.

Justo A, Minnis AM, Ghignone S, Menolli N Jr., Capelari M, Rodriguez O, Malysheva E, Contu M, Vizzini A. 2010 - Species recognition in Pluteus and Volvopluteus (Pluteaceae, Agaricales): morphology, geography and phylogeny. Mycological Progress 10(4): 453-479. http://dx.doi.org/10.1007/s11557-010-0716-z

Justo A, Vizzini A, Minnis AM, Menolli N Jr., Capelari M, Rodriguez O, Malysheva E, Contu M, Ghignone S, Hibbett DS. 2011 - Phylogeny of the Pluteaceae (Agaricales, Basidiomycota): taxonomy and character evolution. Fungal Biology 115: 1-20. http://dx.doi.org/10.1016/j.funbio.2010.09.012

Kornerup A, Wanscher JH. 1978 - Methuen handbook of colour. 3rd ed. Eyre Methuen, London. $243 \mathrm{p}$.

Kulkarni SM. 1990 - Contribution to lignicolous Basidiomycetes flora of S.W. India - II. Geobios New Reports India 9(1), 14-17.

Kulkarni SM. 1992 - Amanita konkanensis: A new species of Agaricales. Biovigyanam 18(1), 5658.

Largent DL. 1977 - How to identify Mushrooms to genus I: Macroscopical Features. 1-85.

Leelavathy KM, Manimohan P, Arnolds EJM. 2006 - Hygrocybe in Kerala State, India. Persoonia 19(1), 101-151.

'Lévillé JH. 1846 - Description des champignous de I' herbier de Museum de Paris. Annals of Science \& Natural Botany series 3(5), 111-167.

Manjula B. 1983 - A revised list of the agaricoid and boletoid basidiomycetes from India and Nepal. In: Proceedings of Indian Academy of Sciences (Plant Science) 92(2), 81-213.

${ }^{\Psi}$ Massee G. 1898 - Fungi Exotici I. Bulletin of Misellaneous Information of Royal Botanic Garden, Kew 1898, 113-136.

${ }^{\Psi}$ Massee G. 1899 - Fungi Exotici II. Bulletin of Misellaneous Information of Royal Botanic Garden, Kew 1899, 164-185.

${ }^{\Psi}$ Massee G. 1901 - Fungi Exotici III. Bulletin of Misellaneous Information of Royal Botanic Garden, Kew 1901, 150-169.

Mohanan C. 2011 - Macrofungi of Kerala. KFRI Handbook No. 27, Kerala Forest Research Institute, Peechi, Kerala, India 597 p.

Narendra DV, Rao VG. 1976 - Studies into Coprophilous fungi of Maharashtra, India-V. Nova Hedwigia 27, 631-645.

${ }^{\Psi}$ Parandekar SA. 1964 - A contribution to the fungi of Maharashtra. Journal of University of Poona, Science \& Technology Sections 26, 57-65. 
Patil MS. 1978 - Some fleshy fungi from Maharashtra - III. Indian Phytopathology 31, 32-35.

${ }^{\Psi}$ Patil MS, Thite AN - 1977. Fungal flora of Radhanagri, Kolhapur. Journal of Shivaji University (Science) 17, 149-162.

${ }^{\Psi}$ Patil MS, Thite AN. 1978 - Fungal flora of Amboli (Ratnagiri). Journal of Shivaji Univesity (Science) 18, 219-224.

${ }^{\Psi}$ Patil SD, Nair LN, Kapandis BP. 1979 - Studies on fleshy fungi of Western India. Journal of University of Poona, Science \& Technology 52, 349-354.

Pegler DN. 1977 - A preliminary agaric flora of East Africa. Kew Bulletin Additional Series VI. Kew, Royal Botanic Gardens, Kew 620 p.

Pegler DN. 1983 - The Genus Lentinus: A World Monograph. Kew Bulletin Additional Series X, Royal Botanic Gardens, Kew 281p.

Purushothama KB, Natarajan K. 1987 - Amanita flavofloccosa - An addition to Indian Agaric Flora. Current Science 56: 1073-1074.

Sathe AV, Deshpande S. 1979 - Chlorolepiota - A new genus of Agaricales (Mushrooms) from India. Current Science 48(15), 693-695.

Sathe AV, Deshpande S. 1980a - A new species of Pholiota from India. Current Science 49(13), 517-518.

Sathe AV, Deshpande S. 1980b - Agaricales (Mushrooms) of Maharashtra State. In: Agaricales (Mushrooms) of South West India. Maharashtra Association for the Cultivation of Science, Research Institute, Pune 9-42.

Sathe AV, Deshpande S. 1982 - Agaricales of Maharashtra. In: Advances in Mycology \& Plant Pathology: Proceeding[s] of the National Symposium Held at Calcutta on 22nd, 23rd September, 1979, eds. S.B. Chattopadhyay \& N. Samajpati, Oxford \& IBH Publishing Company 81-88.

Sathe AV, Kulkarni SM. 1979 - A new species of Entoloma from India. Current Science 48(23), 1042-1043.

Sathe AV, Rahalkar SR. 1975 - Agaricales from South West India - I. Biovigyanam 1(1), 75-78.

${ }^{\Psi}$ Sathe AV, Rahalkar SR. 1976 - Proceedings of Symposium on Survey and Cultivation of edible mushrooms in India, Reg. Research Laboratory, Srinagar 77-80.

Sathe AV, Sasangan KC. 1977 - Agaricales from South West India - III. Biovigyanam 3(1), 119121.

Sathe AV, Sasangan KC. 1978 - A new species of Lepista from South West India. Current Science 47(19), 739-740.

Senthilarasu G. 2013a - Two interesting Pterula species from Maharashtra, India. Mycosphere 4(4), 766-771. http://dx.doi.org/10.5943/mycosphere/4/4/13

Senthilarsu G. 2013b - A checklist of Ramaria in India and an interesting blue species from Western Ghats. Kavaka (accepted for publication).

Senthilarasu G, Kumaresan V, Singh SK. 2010a - A new species of Hygrocybe in Section Firmae from Western Ghats, India. Mycotaxon 111, 301-307. http://dx.doi.org/10.5248/111.301

Senthilarasu G, Kumaresan V, Singh SK. 2010b - A new species of Entoloma from Western Ghats of India. Mycotaxon 114, 61-65. http://dx.doi.org/10.5248/114.61

Senthilarasu G, Kumaresan V, Singh SK. 2010c - Hygrocybe manadukaensis in Section Firmae from Western Ghats, India. Mycotaxon 114, 343-349. http://dx.doi.org/10.5248/114.343

Senthilarasu G, Sharma R, Singh SK. 2012 - A new species of Volvariella from India. Mycotaxon 119, 467-476. http://dx.doi.org/10.5248/119.467

Senthilarasu G, Singh SK. 2012 - A new species of Lentinus from India. Mycotaxon 121, 69-74. http://dx.doi.org/10.5248/121.69

Senthilarasu G, Singh SK. 2013 - A new species of Stropharia from Western Ghats, India. Mycotaxon 123, 213-220. http://dx.doi.org/10.5248/123.213

Sharma BD, Deshpande S, Pradhan SG. 1986 - A new species of Hygrocybe Kummer from India. Bulletin of the Botanical Survey of India 28(1-4), 171-173.

Singer R. 1986 - The Agaricales in Modern Taxonomy. (4 ${ }^{\text {th }}$ ed.) Sven Koeltz Scientific Books. 
Koenigstein, Germany, 981 p.

${ }^{\Psi}$ Theissen F. 1911 - Fungi aliquot Bombayensis, a revised edition, Blatter Collections, Annal Mycology 9, 153-159.

${ }^{\Psi}$ Thite AN, Kulkarni UK. 1976 - Journal of Bombay Natural History Society 73, 456-463.

Thite AN, Patil MS, More TN. 1976 - Some fleshy fungi from Maharashtra. Botanique 7(2\&3), 77-88.

${ }^{\Psi}$ Thite AN, Patil MS. 1982-83 - Journal of Shivaji University 21, 123-127.

Trivedi TK. 1972 - Agaricales of Nagpur-I. Botanique 3(1), 53-59.

Uppal BN, Patel MK, Kamat MN. 1935 - The Fungi of Bombay. Department of Agriculture, Bombay, Bulletin No. 176 of 1934, Government Central Press, Bombay 56 p.

Vaidya JG, Joshi N, Pahade PM. 1991 - A study of Mycetocolous Insect Fauna on Wood Rotting Fungi of Karnala, Raigad District, Maharashtra. Botanique 17(2), 98-104.

${ }^{\Psi}$ Woodrow GW. 1903 - Four interesting Bombay plants. Journal of Bombay Natural History Society $15,36-39$.

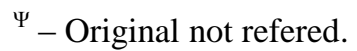

